\title{
Early stages of clastic deposition in the Most Basin (Ohře Rift, Czech Republic, Early Miocene): timing and possible controls
}

\author{
TOMÁŠ MATYS GRYGAR, KAREL MACH, Michal HoŠEK, Petr SCHNABL, MATHIEU MARTINEZ \& \\ MAGDALÉNA KOUBOVÁ
}

\begin{abstract}
This study examines the early stages of clastic deposition above the main coal seam in the Most Basin (Ohře Rift, NW Czech Republic). Eight drill cores were subjected to chemical analysis by X-ray fluorescence spectroscopy (XRF) and cation exchange capacity determination (CEC) to corroborate the local chemostratigraphic scheme and extend its temporal and spatial ranges. Additionally, four drill cores were subjected to palaeomagnetic polarity analysis for magnetostratigraphic dating, and two cores were subjected to the frequency analysis of variations in elemental compositions to obtain cyclostratigraphic patterns and more detailed insight into depositional dynamics. We demonstrate that a local lake was present in the Bílina area from the end of palaeomagnetic chron C5Er through chron C5En (18.524-18.056 Ma according to the Astronomically Tuned Neogene Time Scale 2012) to the beginning of the C5Dr chrons. This finding extends the previous age models for the Most Formation by more than $0.5 \mathrm{My}$ (18.6 to 17.9 Ma). The chemostratigraphic scheme, which is based on variations in the concentrations of $\mathrm{K}$ and the values of CEC, was successfully extended from the basin centre to its north-east periphery, which reflects the basin-wide environmental changes that terminated the peat accumulation (coal formation) in the basin. The basin-wide lacustrine body formed by the coalescence of local lakes and the flooding of the remaining peatlands $c a$. 17.8 Ma (during C5Dn), which is coeval with the substantial reduction of the Antarctic ice sheet prior to the onset of the Miocene climatic optimum (MCO). The Most Basin deposits are the most detailed (with respect to temporal resolution) continental sedimentary archive of the time period preceding the MCO that have not been described to date. - Key words: cyclostratigraphy, chemostratigraphy, lake sediments, climate forcing, Burdigalian.
\end{abstract}

\begin{abstract}
Matys Grygar, T., Mach, K., HoŠEK, M., Schnabl, P., Martinez, M. \& KoubovÁ, M. 2017. Early stages of clastic deposition in the Most Basin (Ohře Rift, Czech Republic, Early Miocene): timing and possible controls. Bulletin of Geosciences 92(3), 337-355 (11 figures, 2 tables), Czech Geological Survey, Prague, ISSN 1214-1119. Manuscript received January 1, 2017; accepted in revised form June 27, 2017; published online September 30, 2017; issued September 30, 2017.

Tomáš Matys Grygar \& Michal Hošek, Institute of Inorganic Chemistry AS CR, v.v.i., 25068 Řě,, Czech Republic; grygar@iic.cas.cz, hosek@iic.cas.cz・Karel Mach, North Bohemian Mines, j.s.c., ul. 5. května 2013, 418 01, Bílina, Czech Republic; mach@sdas.cz・Petr Schnabl, Institute of Geology of the CAS, v.v.i., Prague, the Czech Republic; schnabl@gli.cas.cz・Mathieu Martinez, MARUM, Universität Bremen, Leobener Straße 8, D-28359 Bremen, Germany; mmartinez@marum.de•Magdaléna Koubová, Czech Geological Survey, Geologická 6, 15200 Praha 5, Czech Republic; magdalena.koubova@geologycz
\end{abstract}

Recent studies of sea level fluctuations during the Cretaceous highest sea level (Uličný et al. 2014) have shown that distinguishing between local/autogenic forcings (i.e. tectonic, palaeotopographic) and global/allogenic forcings (i.e. climatic, eustatic) in pre-Pleistocene sedimentary archives is difficult. Researchers mainly perform this intricate task (distinguishing between local and global controls in basin fills) to improve the temporal resolutions of environmental archives; this may be achieved with sediments that were deposited at higher sedimentation rates than in pas- sive continental margins/ocean floors; however, these provide most of the reference records for climate evolution on longer timescales (Zachos et al. 2001). However, higher sedimentation rates are usually caused by active subsidence that, in turn, generates a less stable sedimentary environment in which local/autogenic forcing may be superimposed on the climatic control. The most robust approach to distinguishing between local and global forcings is to extend the spatial scale of the research by (i) deciphering the basin architecture (Uličný et al. 2008, 2014; Valero et al. 


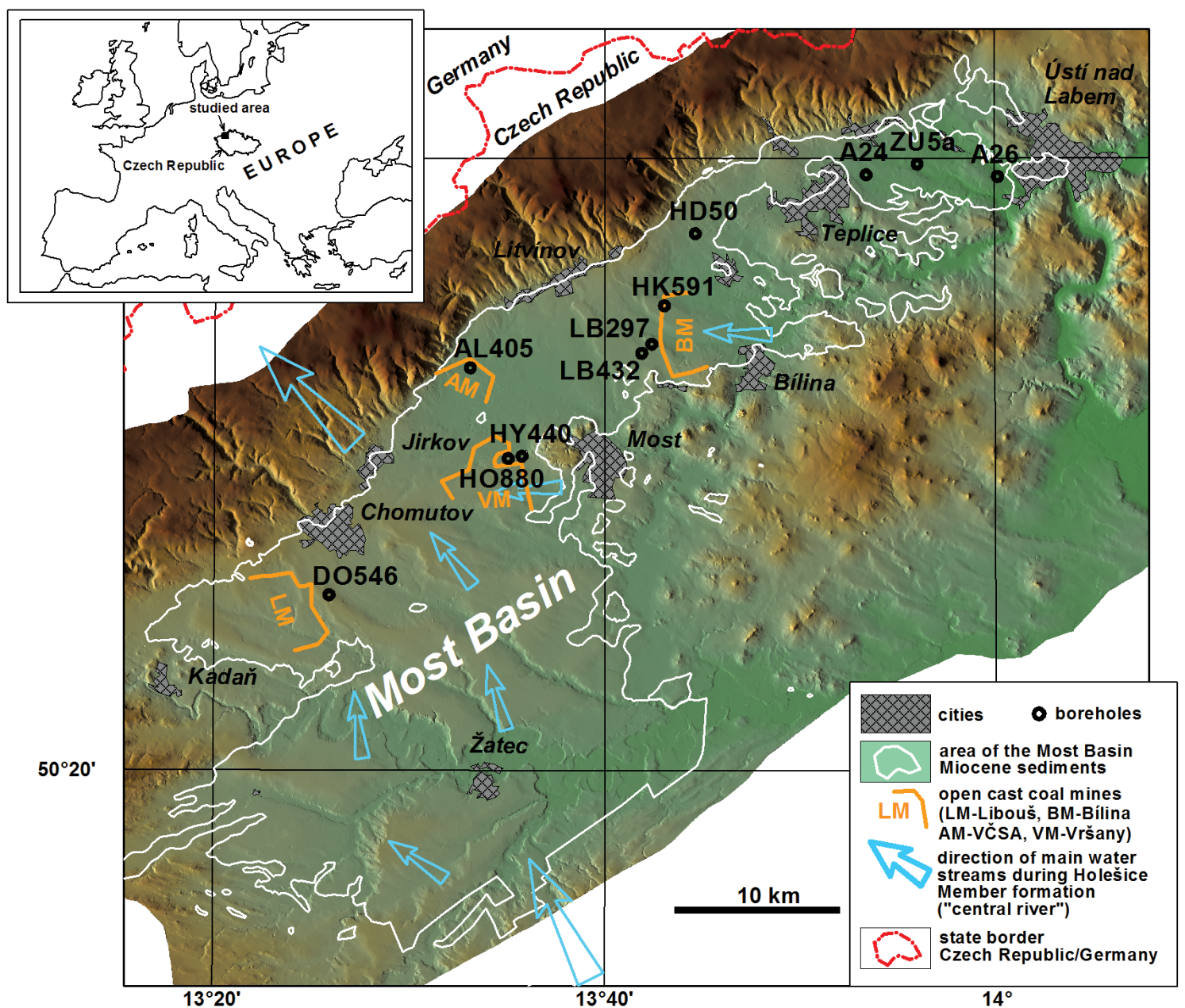

Figure 1. Map of study area with core position.

2017) or (ii) comparing sedimentary archives from remote (tectonically independent) areas (Ied et al. 2011). In practice, less robust approaches are usually chosen, such as in the Most Basin, in which the sedimentary strata are so monotonous that archival datasets from geological surveys cannot be used and a complete basin analysis is not affordable. In addition, the basin periphery (nearshore lacustrine facies) has not been preserved (or has not yet been identified).

The Miocene deposits of the Most Basin (Figs 1,2) include stratigraphically correlated strata of the main coal seams of the Holešice Member (Mach 2003, Mach et al. 2014, Novotný \& Mach 2016), poorly correlated clastic deposit of local fluviodeltaic and lacustrine systems above the coal (i.e. clastic sediments below the Holešice/Libkovice boundary), and stratigraphically correlated lacustrine sediments of the Libkovice Member with a variety of laterally stable local chemostratigraphic horizons (Matys Grygar \& Mach 2013a, b; Matys Grygar et al. 2014; Fig. 2). The clastic deposition above the main coal seam closely preceded the onset of the Miocene Climatic Optimum
(MCO) (Matys Grygar et al. 2014), which was a temporary warming that included the considerable decay of the Antarctic ice sheet (Levy et al. 2016) and intermittently reversed the persistent Cenozoic cooling trend. The effect of the MCO on continental climates is still under debate; its triggers and precise age are uncertain, partly due to a lack of appropriate sedimentary archives with sufficient timing and temporal resolution. The Most Basin sedimentary archive is thus an attractive target area for describing longer sedimentary archives; it is unique due to its combination of continuity, duration, and temporal resolution (Matys Grygar et al. 2014).

This study focuses on the transition between the coal formation and siliciclastic deposition in the Most Basin during the deposition of the Most Formation to determine whether the timing of that change could have been isochronous at the basin scale. This requires spatial and temporal extensions of the existing chemostratigraphic and magnetostratigraphic frameworks for the Libkovice Member sediments (Matys Grygar \& Mach 2013a, b; Matys Grygar et al. 2014, and unpublished data). To do this, we 
(1) extend the age model to the deposits of the Bílina local lake (i.e. the sediments of the Holešice Member) and (2) include the Most Basin periphery (Teplice-Ústí nad Labem, Háj u Duchcova) into the scheme that is valid for the central part of the basin. The strategic aim of this paper was to evaluate the hypothesis that the basin-wide lacustrine transgression over the former peat swamps and local lakes in the Most Basin was isochronous and thus was possibly driven by changes in climate, rather than by local factors.

\section{Geological setting}

The Most Basin is the largest of the four basins in the Ohře Rift, which is part of the European Cenozoic Rift System; this system represents a response of Central Europe to the Alpine and Pyrenean orogenesis (Ziegler \& Dèzes 2007). The Most Basin is a graben structure that was initiated by the end of the Eocene and continued until the Early Miocene. It failed to grow after the coalescence of local faults and the formation of mature faults occurred with a change of the orientation of extension from oblique to orthogonal to the rift axis (Rajchl et al. 2009). Subsequent uplift since the Middle Miocene (Ziegler \& Dèzes 2007) caused the erosion of the top and marginal parts of the basin fill. The basin deposition began in variegated environments (i.e. volcanic rocks, their weathering products, local fluvial systems, and swamps), continued in vast peat swamps, and culminated in a basin-wide lake (Pešek et al. 2010, Mach et al. 2014).

Rajchl et al. (2009) attributed the deposition of clastics over the former peat swamps to an increased subsidence rate. However, a detailed analysis of sediment bodies in the Most Basin showed that the extensive lacustrine clastic strata above the coal seam caused the compaction of the underlying peat to one-seventh of its former thickness, compaction of the fluvial clays to one-third of their former thickness, and negligible compaction of the fluvial sands (Hurník 1972, Mach 2003, Novotný \& Mach 2016). Studies of fluvial and deltaic sediment bodies embedded in the local coal seam demonstrated that the compaction of the peat strata contributed to the formation of accommodation space for the fluvial clastics (Dvořák \& Mach 1999, Rajchl \& Uličný 2005, Rajchl et al. 2008, Mach et al. 2013), Overviews of this peat compaction and examples from other basins are given by Van Asselen et al. (2009), Van Asselen (2011), and Widera (2015; 2016a, b).

The peat accumulation was terminated by fluviolacustrine deposition, after which a basin-wide lake was formed (the Libkovice Member). Orbital forcing has been identified in the geochemical signatures of the Libkovice Member sediments, including the $\mathrm{Al} / \mathrm{Si}$ and $\mathrm{K} / \mathrm{Ti}$ ratios and CEC (Matys Grygar et al. 2014, and unpublished data). These sediments are so monotonous in appearance that

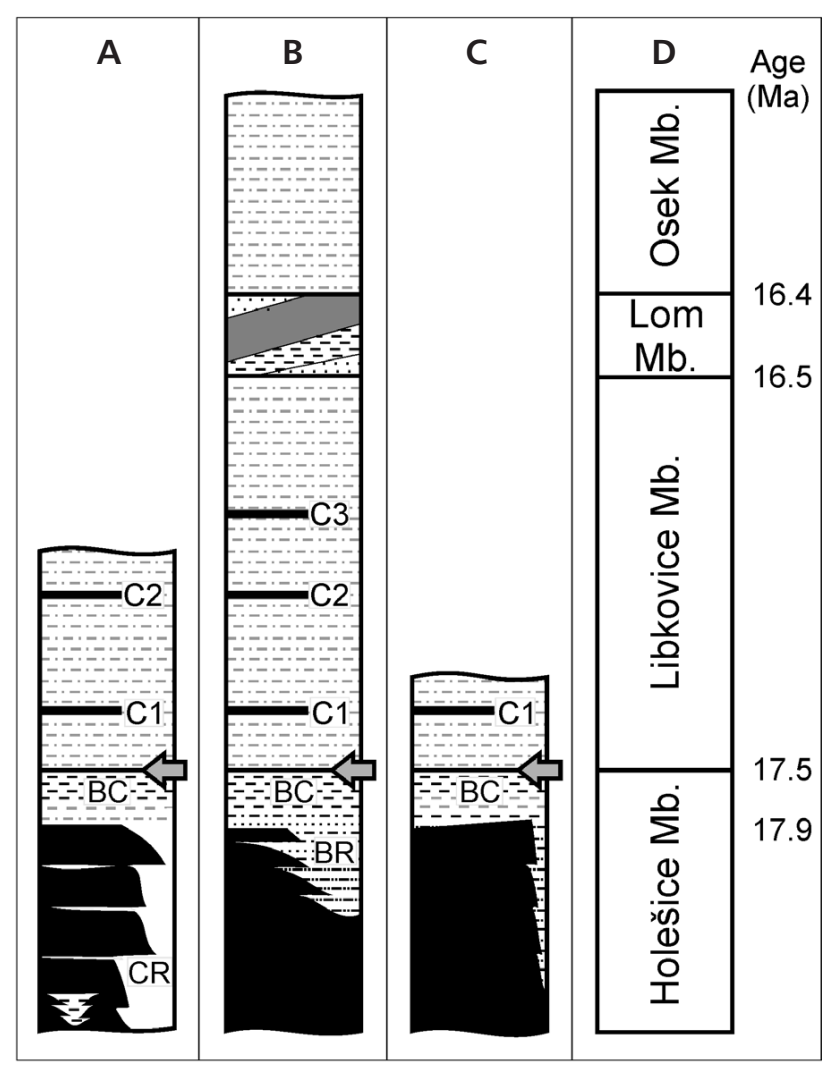

main coal seam clastic sediments
$\square$ coaly clay, clayey coal
$\square$ kaolinite clay illite-smectite silt-clay

$\therefore$ sand, sand admixture

C\# crandallite horizons

CEC step horizon

BC Břeštany clay and their lateral analogues

BR Bílina River deposits including delta heteroliths

CR central river deposits

Figure 2. Stratigraphic scheme for the clastic sediments of the Most Formation above the main coal seam. In Libouš Mine area (A), Bílina Mine area (B), and Ústí nad Labem-Teplice area (C) the upper part of the lacustrine sequence is missing, while in the Bílina Mine area the most complete sequence has been preserved. Panel D shows members of the Most Formation with approximate time scale taken from Matys Grygar et al. (2014).

they can only be differentiated by mineralogical (Sloupská 1985) or elemental analyses (Matys Grygar \& Mach 2013a, b). The biostratigraphic age constraints of the Most Formation are limited to the identification of the European mammal zone MN3 at the base of the main coal seam (Fejfar et al. 2003), which started at 20.5 Ma (Schlunegger et al. 2007). Broad regional correlations of macrofloral 
remnants (leaves and fruits) also assign the age of the Most Formation to the Late Burdigalian (Kovar-Eder et al. 2001, Mach et al. 2014, and references therein).

We recently proposed a hypothesis that the overall peat accumulation in the basin was terminated by enhanced precipitation and the subsequent enhanced input of fluvial clastics and that the lake progradation was facilitated by peat compaction (Matys Grygar et al. unpublished data). We thus gathered novel results on the early stages of lacustrine development in the Most Basin using magnetic polarity dating to shed light on the early stages of clastic deposition over the coal seam.

\section{Methods}

\section{Element and clay mineral analyses}

Elemental concentrations were obtained using the MiniPAL4 (drill core LB297), Epsilon $3^{\mathrm{XLE}}$ (HD50, parts of A24, A26, ZU5A) and Epsilon $3^{\mathrm{X}}$ (LB432, part of A24) $\mathrm{X}$-ray fluorescence (XRF) spectrometers, all which were provided by PANalytical (the Netherlands) and contained an energy dispersive detector. The samples were powdered using a Pulverisette 6 planetary mill (Fritsch, Germany) and poured into measuring cells with Mylar foil bottoms without further pre-treatment (i.e. no fusion, no pressing). The readings of the analytical signals (raw XRF signals) were calibrated by the chemical analysis of selected specimens by accredited laboratories of the Czech Geological Survey and by the geological laboratory in the Geology section, Faculty of Science, Charles University, Prague. This analytical procedure (calibrated by XRF) is simple, economic, and non-destructive. To limit possible matrix effects, such as variable organic matter contents, we preferentially evaluated the signal ratios of elements with similar spectral line energies, namely, $\mathrm{Al} / \mathrm{Si}, \mathrm{K} / \mathrm{Al}$, and $\mathrm{Zr} / \mathrm{Rb}$; the calibrations of these element ratios produced higher regression coefficients than the corresponding single-element calibrations. Additionally, $\mathrm{Al} / \mathrm{Si}$ is a broadly applicable proxy for the grain size of mature fluvially sorted sediments (Bouchez et al. 2011, Matys Grygar \& Popelka 2016). The $\mathrm{K} / \mathrm{Al}$ ratio is among the simplest proxies for relatively intense chemical weathering (Clift et al. 2014). The $\mathrm{Zr}$ concentration, or $\mathrm{Zr} / \mathrm{Rb}$ ratio, reflects the percentages of coarse silt/fine sand compared to the fine silt/clay fractions (Jones et al. 2012, Matys Grygar \& Popelka 2016).

The cation exchange capacity (CEC) was determined using a $[\mathrm{Cu} \text { (trien) }]^{2+}$ complex (Meier \& Kahr 1999) using the protocol described by Grygar et al. (2009). The CEC value is proportional to the percentage of smectite structures in sediments; it does not require the separation of the clay size fraction and produces reproducible quantitative results. The CEC variations are important features of the Holešice and Libkovice member sediments (Sloupská 1985, Matys Grygar \& Mach 2013a, b).

$\mathrm{X}$-ray diffraction analysis (XRD) was performed using a D8 Advance diffractometer (Bruker, Germany), a scanning range of $3-50^{\circ}$ and a step of $0.015^{\circ}$ and $0.8 \mathrm{~s}$, with an automatic divergence slit of $10 \mathrm{~mm}$. Conventional procedures were used for the separation and identification of clay minerals. Selected sediment samples were subjected to the analysis of glycol vapour-saturated oriented specimens, and clay minerals were then identified by their basal spacing. The main non-clay mineral admixtures are quartz (detrital) and siderite (authigenic), which is consistent with the known composition of the Most Basin clastic sediments above the main coal seam.

\section{Magnetic polarity analysis}

The drill cores were sampled for palaeomagnetic analysis at a sampling step of 1 metre. The vertical orientation of the samples was marked to interpret the magnetic inclination and polarity. Each sample was placed into a cubic, non-magnetic cell with an internal volume of $6.7 \mathrm{~cm}^{3}$ and demagnetized by an alternating magnetic field in a $2 \mathrm{G600}$ apparatus; the remanent magnetization was measured using a $2 \mathrm{G} 7554 \mathrm{~K}$ cryogenic magnetometer (both by $2 \mathrm{G}$ Enterprises, Applied Physics Systems, Mountain View, CA). Additional rock magnetic parameters were acquired using a Kappabridge MFK1 (AGICO Ltd., Brno, Czech Republic). The anisotropy of magnetic susceptibility (AMS) was detected to determine the primary magnetic and sedimentary structures.

The magnetic polarity and inclination were determined using principal component analysis (PCA) (Kirschvink 1980) with the Remasoft 3 program. The magnetic polarity zones (MZs) were identified as continuous intervals of the same polarity after the exclusion of PCA results of which (i) the absolute values were less than $10^{\circ}$, except for the zone boundaries, where low inclinations were an inevitable consequence of magnetic pole wandering, and (ii) both accepted neighbours were of the opposite sign, except for the zone boundaries (Matys Grygar et al. 2014). The sampling density was sufficient to follow these strict criteria. The magnetic inclinations were plotted as consecutively numbered zones and compared to the geopolarity chrons using the ATNTS2012 timescale (Gradstein et al. 2012).

\section{Spectral analyses}

Prior to the analysis of their frequency content, each time series was detrended using a best-fit linear approach for the $\mathrm{Fe} / \mathrm{Al}$ series of the HK591 series and the LOWESS method 
with a coefficient of 0.4 for the K/Al series. Each detrending method was selected to efficiently remove the power of the frequencies closest to 0 without affecting the power of the higher frequencies.

The frequency content of each time series was then explored using a multi-taper method (MTM; Thomson 1982, 1990). Three $2 \pi$-tapers were used to calculate the MTM spectrum ( $2 \pi$-MTM spectrum). Confidence levels were calculated using a robust linear red-noise fit, which was implemented using the Astrochron R-package (Mann \& Lees 1996, Meyers 2014). The changes in the frequency content throughout the series were explored using the sliding-window Fast Fourier Transform (evolutive spectrum) weighted by one Slepian sequence (Martinez et al. 2013, 2015). This method consists of dividing the series into equally wide short intervals and measuring the frequency content of each of these subseries. The result is a spectrum in three dimensions, or a spectrogram. The larger the subseries are, the higher the frequency resolution is, but information is lost in the evolution of the periods throughout the series. Thus, for the K/Al series of core HD50, two spectrograms were performed; one focused on the low frequencies with a 60-m-widesubseries, and one focused on the high frequencies with a 20 -m-wide subseries. Because the Fe/Al series of HK591 only contains high frequencies (or short periods), one spectrogram was performed using a 20-m-wide subseries.

The evolution of a particular band of interest throughout the time series was observed using Taner filters (Taner 2003). The amplitude modulation of the cycles of interest was calculated using a Hilbert transform on the filter of the frequencies of interest.

\section{Chemostratigraphic scheme for the Most Basin clastic sediments}

Figures 2 and 3 show the major chemostratigraphic markers for the Most Basin and their lithological descriptions, which are based on several drill cores and local geochemical surveys that have been described in detail elsewhere (Matys Grygar \& Mach 2013a, b; Matys Grygar et al. 2014). This scheme has been used for the clastic sediments in the Bílina Mine area, which are up to $300 \mathrm{~m}$ thick, and in the Libouš Mine area, where they are $120 \mathrm{~m}$ thick. In some parts of the Bílina Mine area, these clastic strata also include approximately $150 \mathrm{~m}$ of the Holešice Member clastics of a local lake with the Bílina delta (Dvořák \& Mach 1999, Mach et al. 2013). Several dark grey silty clays with very fine laminations have been distinguished by field geologists in the Holešice clastics in the Bílina Mine; they are interbedded with heteroliths of the Bílina delta with occasional fine sandy strata (Dvořák \& Mach 1999, Mach et al. 2013).
The Břeštany clay is a 10- to 15-m-thick layer of kaolinite-rich fine sediments with 7-8 siderite beds that is best known and documented in the Bílina Mine area. This unit is situated immediately above the uppermost Bílina delta heteroliths. Lateral equivalents of these strata have also been identified in the Tušimice area (Matys Grygar et al. unpublished data), where a frequency analysis identified their precession forcing ( $c a .20 \mathrm{ky}$ ). In the Bílina area, this rate has not yet been demonstrated, because the siderite beds have spacings of only 2-3 $\mathrm{m}$ and thus require dense analyses (i.e. a few sediment samples per metre) to identify them. They are characterized in more detail in this study.

The abrupt increase (step) of the CEC immediately above the Břeštany clay (i.e. the increase in smectite structures at the expense of kaolinite) has been proposed to be a marker for the Holešice/Libkovice boundary in the areas of the Bílina and Libouš mines (Matys Grygar \& Mach 2013a, b). The sediments above this step are fine silty clays/clayey silts without sandy intercalations and with three identified crandallite horizons, which are a few $\mathrm{cm}$ thick and are composed of a mixture of kaolinite and crandallite. Local crandallite (Ca-Sr aluminophosphate) is a mineral from the aluminophosphate-sulphate group (APS; Dill 2001). The Libkovice Member exhibits a very specific pattern of $\mathrm{Al} / \mathrm{Si}, \mathrm{K}$, and $\mathrm{Sr}$ concentrations that is suitable for the wiggle-matching correlation of strata in the areas of the Bílina and Libouš mines (Matys Grygar et al. 2014, and unpublished data).

\section{Results}

\section{Clay assemblage and CEC}

The CEC analyses identified two patterns (Fig. 3). The first pattern includes low values above the main coal seam (LB297, LB432, AL405, and HD50) followed by a stepwise increase to values $>0.1 \mathrm{mmol} \mathrm{Cu} / \mathrm{g}$ (LB297, HD50), which is a pattern typical of the Bílina Mine area (Matys Grygar \& Mach, 2013a, b). The second pattern consists of relatively high CEC values immediately above the main coal seam followed by an intermittent decrease and a final and persistent return to values above $\sim 0.1 \mathrm{mmol} \mathrm{Cu} / \mathrm{g}$ (A24, ZU5A). The latter pattern is typical of the Libous Mine area (DO546, SP257, Matys Grygar \& Mach 2013a, b). In both patterns, we assign the pass through the threshold of $\sim 0.1 \mathrm{mmol} \mathrm{Cu} / \mathrm{g}$ to stable high values as the diagnostic CEC step, which is indicated by an arrow in Fig. 3 and other figures. This chemical analysis showed that the strata with low CEC values have greater percentages of $\mathrm{K}^{+}$in the sum of exchangeable cations, which indicates the possible influence of lacustrine and/or pore water chemistry. 
HD50, Háj u Duchcova

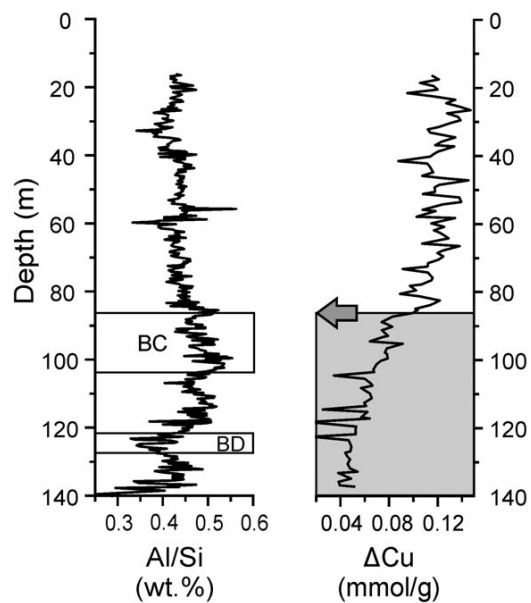

HK591, Bílina Mine area

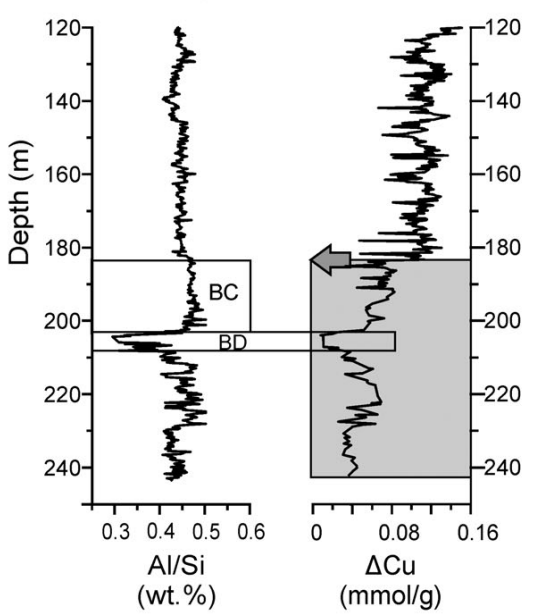

ZU5A, Teplice-Ustí nad Labem
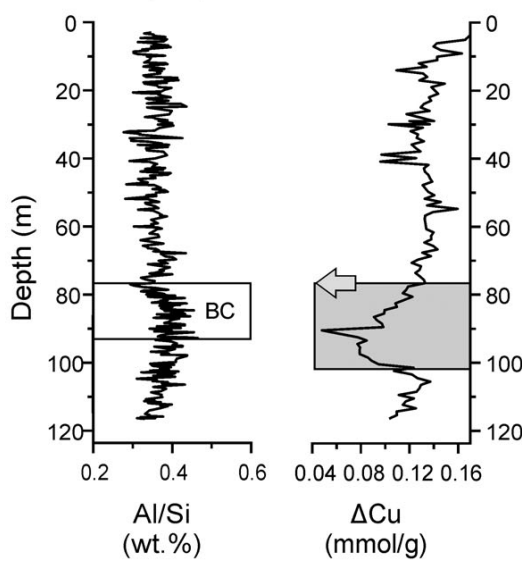

$\checkmark$ CEC step marker BD-Bilina delta sands

Low CEC strata $\quad B C$-Břeštany clay

Figure 3. Examples of Bílina Mine pattern (HD50 and HK591) and Libouš Mine-like pattern (ZU5A) of CEC and Al/Si. CEC profiles are vertically arranged along the CEC step marker (C). The CEC step marker is highlighted by the arrow.

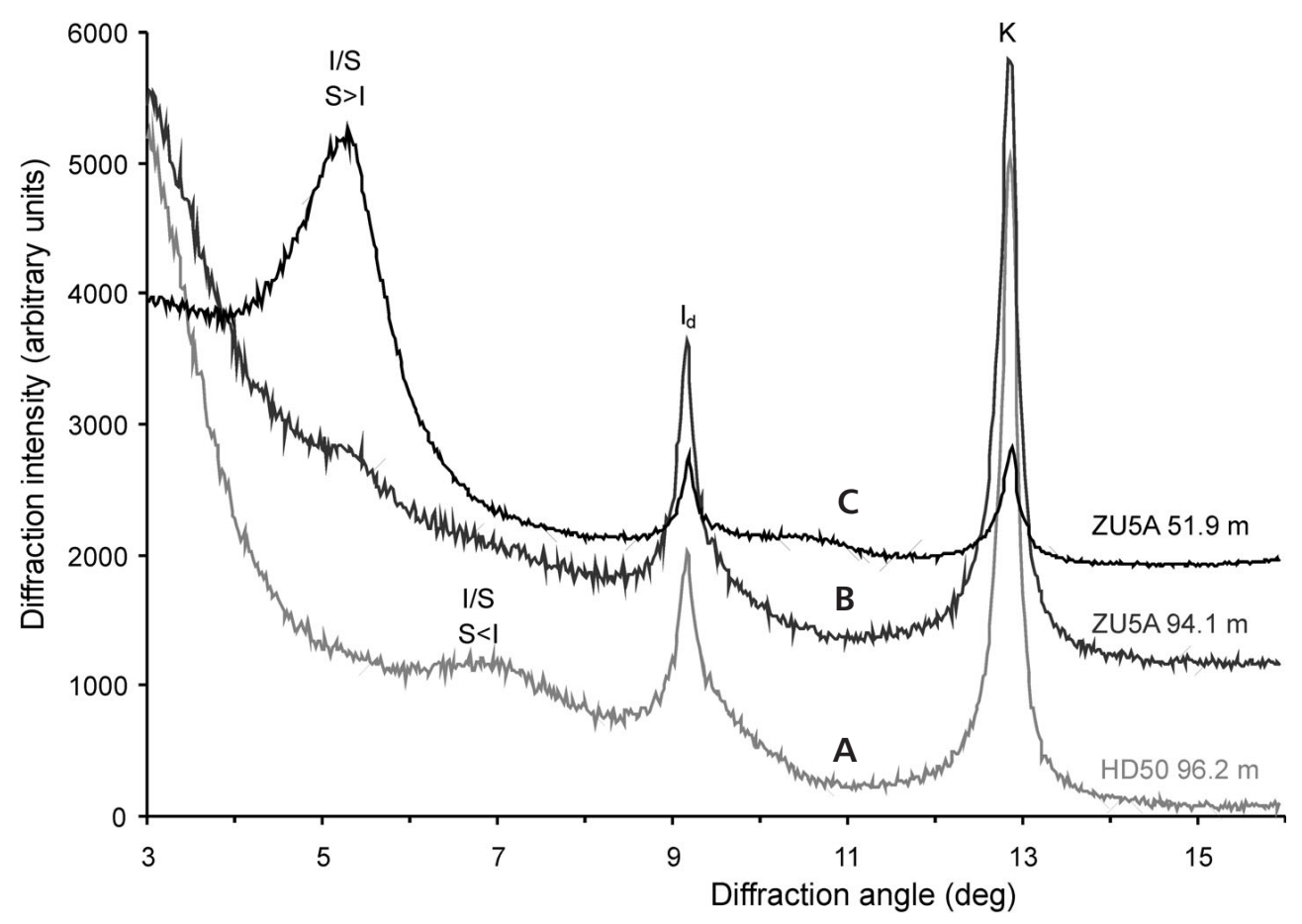

Figure 4. Three typical clay assemblages found in studied cores. Low-CEC strata rich in kaolinite (A), low-CEC strata with illite-rich I/S in Břeštany clay (B), and high-CEC strata with smectite-rich I/S typical for the Libkovice Member (C). Only basal diffraction diagnostic for the main clay-mineral types are shown.

The CEC values of the sediments are proportional to their total contents of expandable clay structures, particularly interstratified illite/smectite (I/S) (Fig. 4). Although the CEC values can decrease when the clay size fractions are diluted by quartz, this can easily be revealed by the presence of decreased $\mathrm{Al} / \mathrm{Si}$ and increased $\mathrm{Zr}$ or $\mathrm{Zr} / \mathrm{Rb}$ ratios, which have not been identified in the sandy intercalations of the Bílina delta. The kaolinite-rich clays, which are typically fine clastics located in the main coal seam, a few metres immediately above the coal seam and in the
Břeštany clay, have high $\mathrm{Al} / \mathrm{Si}$ ratios and low $\mathrm{CEC}$ values due to their very low concentrations of smectite structures. The diagnostic CEC step (the Holešice/Libkovice boundary) is not controlled by the mean grain size because it occurs within clayey strata in all of the drill cores (Fig. 3); it is always associated with a minor decrease of $\mathrm{Al} / \mathrm{Si}$ due to the enrichment by I/S rich in smectite at the expense of kaolinite (Fig. 3). A very specific feature of the low-CEC clayey unit above the main coal seam in the Bílina Mine area (LB297, HK591) and Háj u Duchcova is the presence 
Figure 5. Siderite beds in HK591 core near the Holešice/Libkovice boundary in the Bílina Mine area with position of the CEC step marker (the arrow) and $\mathrm{K}$ minima. Strata of Břeštany clay (BC), Bílina delta sands (BD), and dark clay (DC) are shown. The dashed vertical lines are placed manually to show steps in $\mathrm{Al} / \mathrm{Si}$ and $\mathrm{Fe} / \mathrm{Al}$ in boundaries of sedimentary units. Separations of neighbouring siderite beds in Břsštany clay and Libkovice $\mathrm{Mb}$. sediments are shown in the panel with Fe percentage.

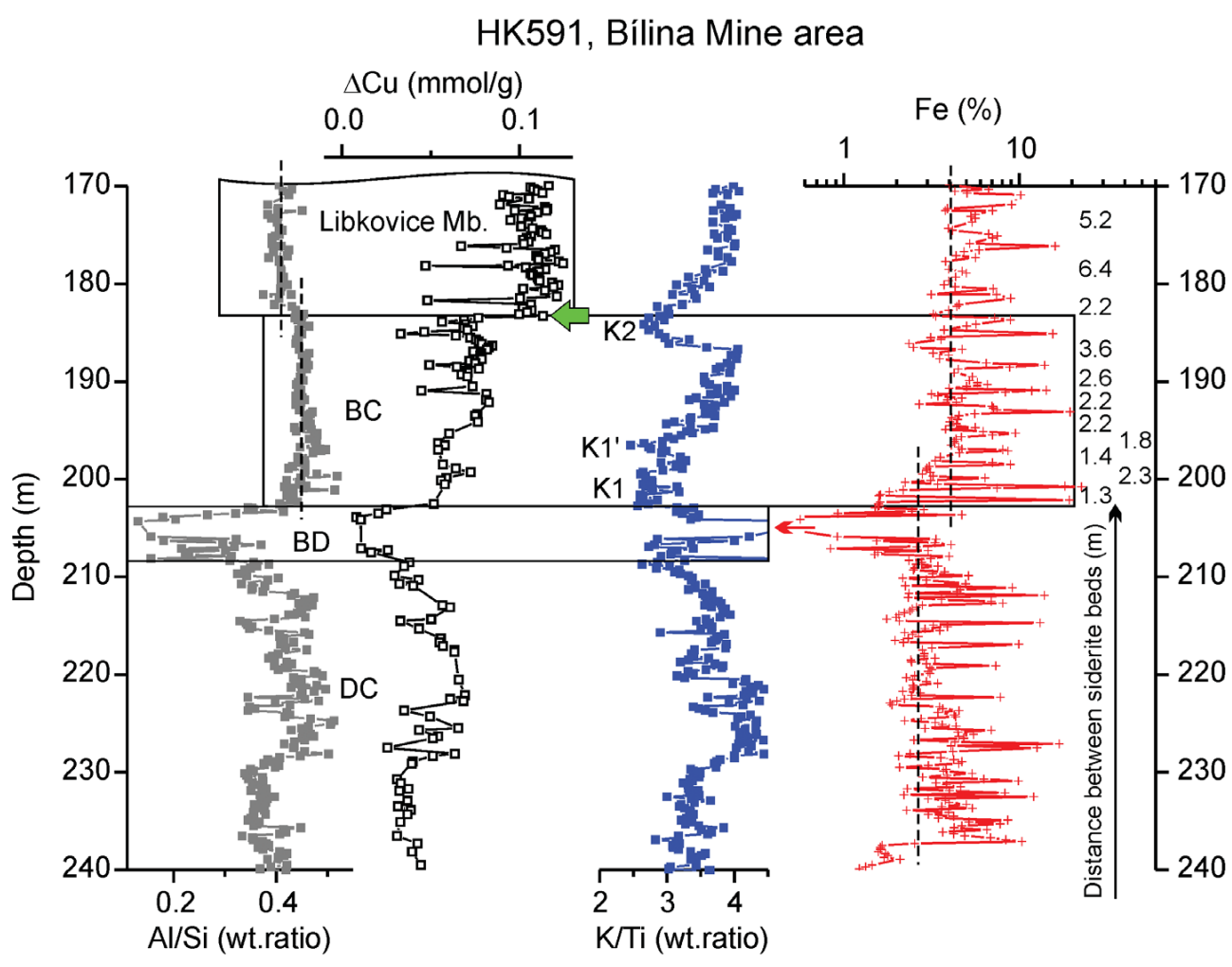

of site-specific I/S with 30\% smectite structures (i.e. illite-rich I/S) (Fig. 4). This mineral is either absent in all of the other analysed sediments or it is completely masked by a considerable amount of I/S with 70-80\% smectite layers. The clay mineral analysis thus supports the distinction between the CEC patterns of the Bílina Mine type (LB297, HK591, and HD50) and the pattern with a local minimum of CEC; in the latter, the CEC minimum is due to the dilution of I/S with $70-80 \%$ smectite by major kaolinite, whereas in the former, it is due to the presence of a different expandable clay mineral.

\section{Variations in Fe and Sr concentrations}

Most of the $\mathrm{Fe}$ in the Most Basin deltaic-lacustrine sediments, which ranges in concentration from a few percent to ca. $25 \%$, is present in siderite, which is an early diagenetic product and is volumetrically the main authigenic mineral in the sediments (Dvořák \& Mach 1999). In the lacustrine sediments (i.e. fine, monotonous strata with CEC values above the threshold of $0.1 \mathrm{mmol} \mathrm{Cu} / \mathrm{g}$ ), Fe is enriched compared to the mean upper continental crust (UCC); the Fe/Al ratios in the Libkovice Member sediments are 0.60 and 0.66 in LB297 and HK591, respectively, while the mean UCC value is 0.48 (Rudnick \& Gao 2003). In contrast, the mean $\mathrm{Fe} / \mathrm{Al}$ ratios are typically less than 0.5 in the strata with lower CEC values located immediately above the main coal seam; they are 0.41 in the Bílina delta and pro- delta sediments in both LB297 and HK591 and 0.46 in LB432. A very similar difference between the Fe-depleted Holešice Member and the Fe-enriched Libkovice Member was found in the Libouš Mine area (DO546, SP257, Matys Grygar \& Mach 2013a, b). This feature is not observed in the newly studied drill cores; the sediments above the coal have mean $\mathrm{Fe} / \mathrm{Al}$ ratios ranging between 0.51 and 0.54 in the Teplice-Ústí nad Labem area (A24 and ZU5A) and approximately 0.58 in Háj u Duchcova, with no distinction between the Holešice and Libkovice members. Obviously, the sediment chemistry in the basin is somehow specific to the individual depocentres, and it differs between the early (local) and later (single) lake bodies.

In the kaolinite-rich strata of the Břeštany clay and its lateral equivalents in the Libouš Mine area, the siderite beds, which contain a substantial portion of total Fe, are particularly well developed, regularly spaced, and remarkably laterally stable. The most representative image of these siderite beds is from drill core HK591 (Fig. 5). The same stratigraphically equivalent features were observed in the Libouš Mine area (e.g. DO546 and SP257, Matys Grygar \& Mach 2013a, b) but not in the newly studied drill cores from Háj u Duchcova and the Teplice-Ústí nad Labem area. In LB297, these beds have probably been undersampled, because they are only a few dm thick and have spacing of less than $2 \mathrm{~m}$. The mean $\mathrm{Fe} / \mathrm{Al}$ ratio in the Břeštany clay is 0.50 in LB297, and a value very similar to that of the UCC was found in AL405 (Matys Grygar 2010). 
DO546, Liobouš Mine area

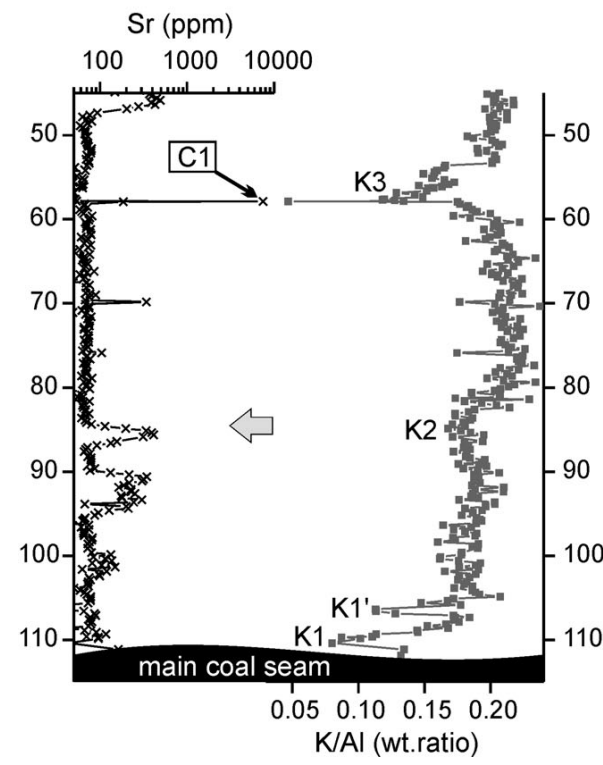

A24, Teplice-Ústí nad Labem

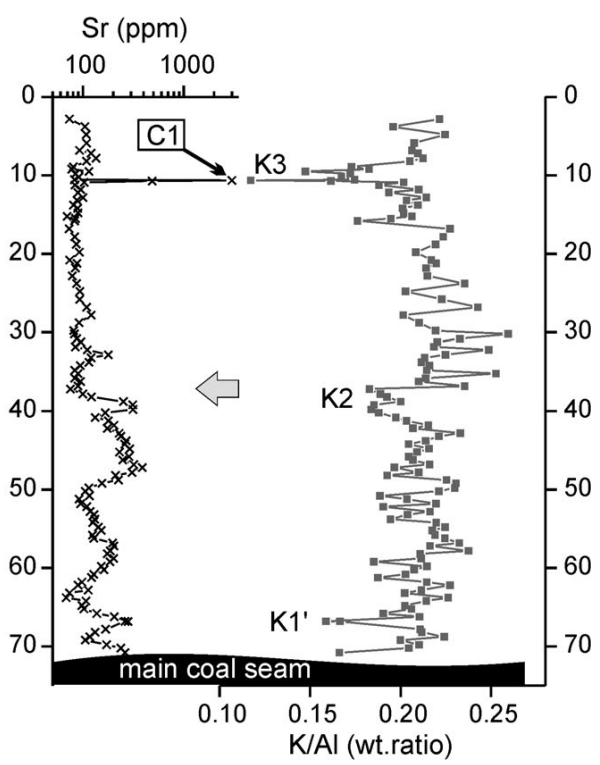

Figure 6. Depth profiles of $\mathrm{Sr}$ and $\mathrm{K} / \mathrm{Al}$ in A24 core (right) and reference core DO546 (Matys Grygar \& Mach 2013a, b) from the Libouš Mine area (left). Position of crandallite horizon assigned to $\mathrm{C} 1$ in of the prominent $\mathrm{K}$ minima is marked.

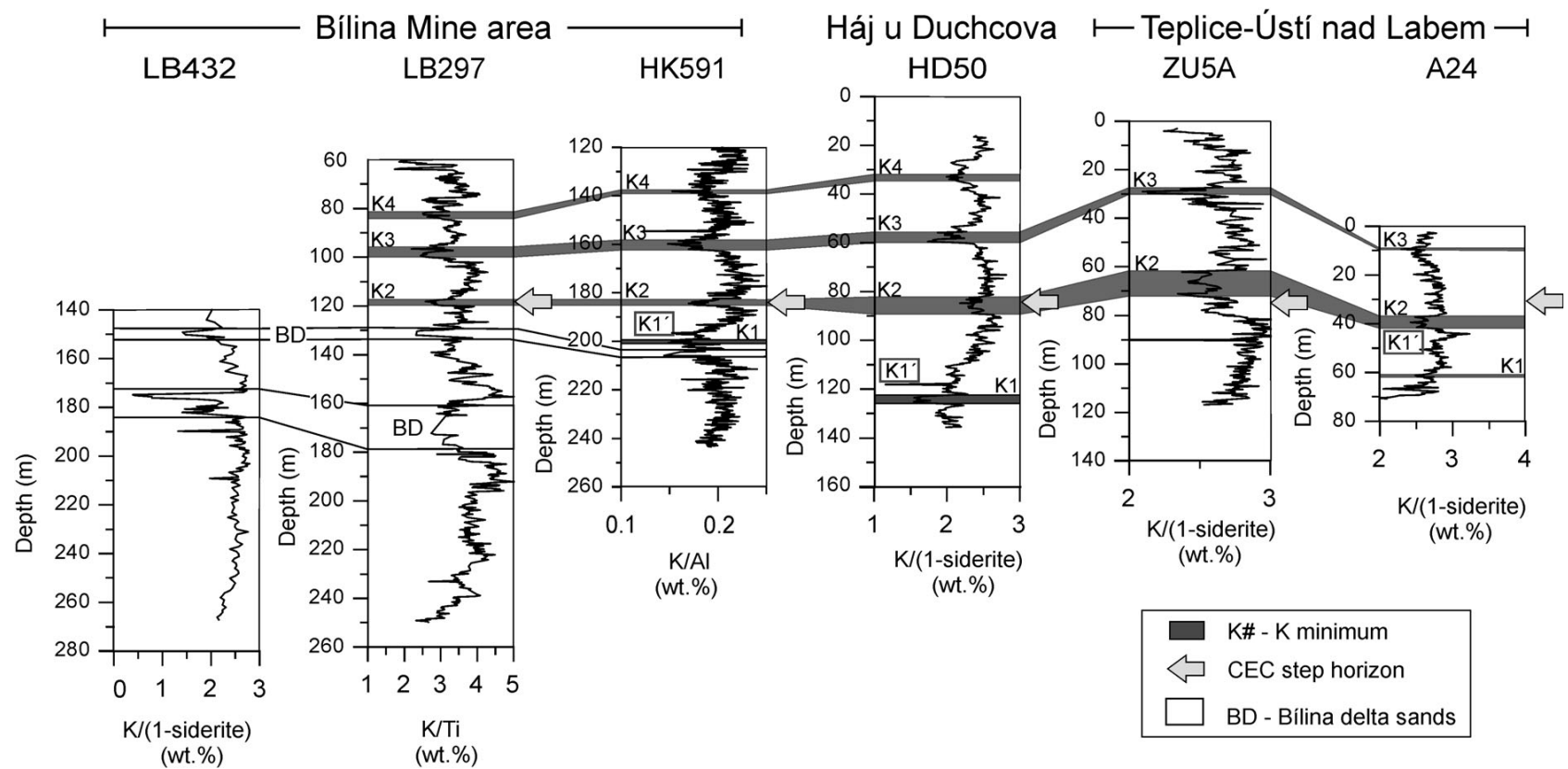

Figure 7. Depth profiles of $\mathrm{K} / \mathrm{Al}$ for studied cores. The profiles are vertically arranged along the CEC step marker highlighted by the arrow.

The Holešice Member sediments in the Bílina Mine area have a different $\mathrm{Sr}$ distribution than the overlying Libkovice Member, although the mean Sr contents of both units are similar (between 80 and $110 \mathrm{ppm}$ in all of the cores of both members). In the Holešice Member, Sr is enriched in broad, irregular, and nearly featureless peaks (Fig. 6). In the Libkovice Member, Sr has a stable "baseline" value of $c a .50 \mathrm{ppm}$ with narrower, up to 3 -m-thick symmetric peaks of up to $300 \mathrm{ppm}$ in the areas of the Bílina and Libouš mines. These peaks are also present in ZU5A but not in HD50 (Fig. 6), which also demonstrates the partially site-specific control over their origin. The maximum $\mathrm{Sr}$ concentrations in the Most Basin sediments are found in crandallite horizons; one was identified in core A24 (Fig. 6). The crandallite horizon in A24 was light grey, less than $1 \mathrm{~cm}$ thick, and included $\mathrm{Al}, \mathrm{Ca}$, and $\mathrm{P}$ as its main elemental constituents (in addition to $\mathrm{O}$ ). 


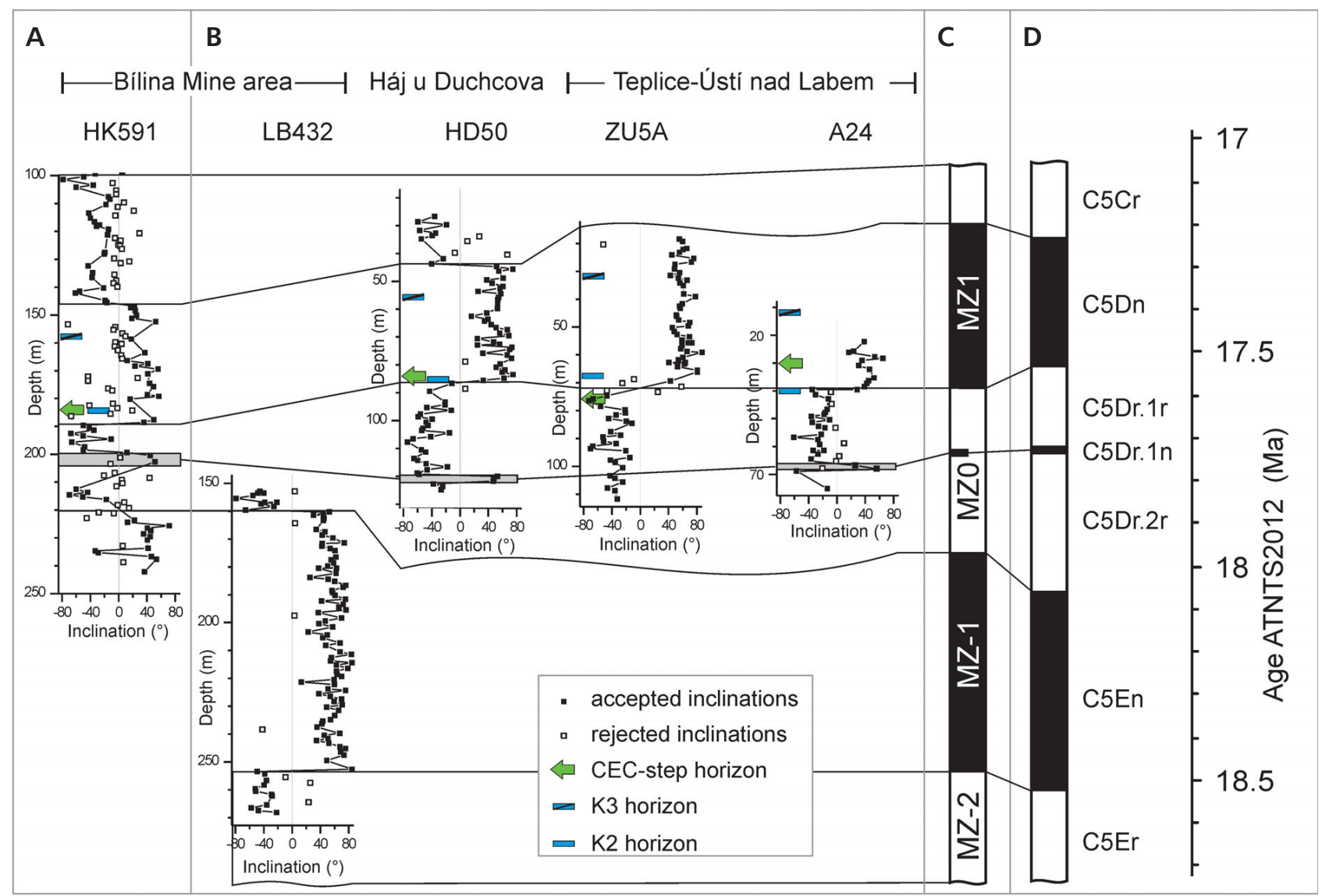

Figure 8. Results of polarity analyses in newly studied cores (panel B) as compared to the lower part of the HK591 core (panel A). The profiles are vertically arranged along the CEC step marker highlighted by the arrow. Panel C shows identified magnetozones and D shows chrons according to ATNTS2012.

\section{Variations in $\mathrm{K}$ and $\mathrm{Ti}$ concentrations}

Both the raw and geochemically normalized K concentrations show characteristic minima in their depth profiles with overall patterns that resemble those known from the areas of the Libouš and Bílina mines. The possible wiggle-matching of the $\mathrm{K}$ profiles in the newly obtained and previously reported drill cores is shown in Fig. 7. In the areas of the Bílina and Libouš mines, both the Aland Ti-normalization of $\mathrm{K}$ provide similarly efficient corrections to suppress the grain-size effects (i.e. the joint dilution of Al-, K-, and Ti-bearing minerals by quartz or siderite); however, at the Háj u Duchcova and Teplice-Ústí nad Labem sites, Ti also has another control and is thus not suitable for use as a straightforward grain-size correction. Titanium is known to be substantially enriched in mafic volcanics compared to UCC; this is also valid in the Most Basin for the clastic deposition occurring before and during the formation of coal (Elznic et al. 1998). The $\mathrm{Ti} / \mathrm{Al}$ ratio is an efficient indicator of sediment provenance (i.e. the contribution of mafic volcanics in the catchment) in the current Ohře River system, which is located to the southwest of the Most Basin (Matys Grygar et al. 2016). The $\mathrm{Ti} / \mathrm{Al}$ ratio varies significantly in the first tens of metres above the main coal seams in HD50, A24, A26, and ZU5A. We thus tested $\mathrm{Al}$ as a normalizing element for $\mathrm{K}$ that is less site-dependent than Ti. We also performed geochemical normalization to correct for variable siderite content, i.e. we recalculated the $\mathrm{K}$ concentration to the non-siderite portion of the sediment samples. The siderite portion was calculated from the Fe percentage.

The raw and normalized K-depth profiles show distinct minima, and the prominent minima are numbered consecutively upward (Figs 6, 7). The successful wiggle-matching of these profiles in the Libkovice Member sediments between the areas of the Bílina and Libouš mines has already been demonstrated (Matys Grygar \& Mach 2013a, b). We show this correlation for the first time for the Holešice Member. The minimum that is denoted K1 (usually with the satellite K1') is located in the first few metres above the main coal seam, K2 is located near the CEC step horizon (Fig. 3), and K3 contains the lowermost crandallite horizon (C1) at its base (Fig. 6). 
Table 1. Summary of polarity reversals, numbering of magnetozones (MZ), and their assignments to magnetochrons. Depths of reversals in LB297 were extrapolated from HK591 and LB432.

\begin{tabular}{|c|c|c|c|c|c|c|c|c|c|}
\hline & \multicolumn{6}{|c|}{ Depth of polarity reversal or excursion (m) } & \multirow[t]{2}{*}{ MZ\# } & \multicolumn{2}{|c|}{ ATNTS2012 } \\
\hline & HK591 & LB297 & LB432 & HD50 & ZU5A & A24 & & Chron & Age $(\mathrm{Ma})$ \\
\hline Zone/chron & & & & & & & MZ3 & C $5 \mathrm{Cn} .3 \mathrm{n}$ & \\
\hline Reversal & 47 & 7 & & & & & & & 16.721 \\
\hline Zone/chron & & & & & & & MZ2 & $\mathrm{C} 5 \mathrm{Cr}$ & \\
\hline Reversal & 146 & 89 & & 40 & & & & & 17.235 \\
\hline Zone/chron & & & & & & & MZ1 & C5Dn & \\
\hline Reversal & 189 & 123 & & 85 & 71 & 39 & & & 17.533 \\
\hline Zone/chron & & & & & & & & C5Dr.1r & \\
\hline Excursion & & & & 121 & & 65 & MZ0 & C5Dr.1n & 17.729 \\
\hline Zone/chron & & & & & & & & C5Dr.2r & \\
\hline Reversal & 220 & 152 & 161 & & & & & & 18.056 \\
\hline Zone/chron & & & & & & & MZ-1 & C5En & \\
\hline Reversal & & 237 & 251 & & & & & & 18.524 \\
\hline Zone/chron & & & & & & & MZ-2 & $\mathrm{C} 5 \mathrm{Er}$ & \\
\hline
\end{tabular}

Table 2. Mean deposition rates $(\mathrm{cm} / \mathrm{ky})$ in individual chrons and cores.

\begin{tabular}{llccccc}
\hline MZ\# & Chron & HK591 & LB297 & LB432 & HD50 & A24 \\
\hline MZ3 & C5Cn.3n & 17 & & & & \\
MZ2 & C5Cr & 19 & 16 & & & \\
MZ1 & C5Dn & 14 & 11 & & 15 & \\
& C5Dr.1r & & & & 18 & 13 \\
MZ0 & C5Dr & 6 & 5.5 & & & \\
MZ-1 & C5En & & 18 & 19 & & \\
\hline
\end{tabular}

\section{Magnetic polarity analysis}

The magnetic polarity was successfully acquired and interpreted in cores LB432 (2 reversals), HD50 (2 main reversals and one short excursion), A24 (1 reversal and one short excursion), and ZU5A (1 reversal) (Tab. 1, Fig. 8). The uncertainty in the reversal position was on the order of a few metres.

The numbering of the magnetic polarity zones and their assignment to magnetic polarity chrons following ATNTS2012 (Gradstein et al. 2012) was derived from the age model for the Libkovice Member in core HK591 (Matys Grygar et al. 2014) and the chemostratigraphic correlation of the cores that was previously shown (Figs 3, 7). Consistent with that assignment, the short normal excursion within the inverse magnetic polarity zone MZ0 that was observed in HD50 (2 samples) and in A24 (2 samples) was attributed to normal excursion C5Dr. $1 \mathrm{n}$, which is similar to the analogous feature in the laterally analogous normal excursion (2 samples) in HK591 (Matys Grygar et al. 2014, and unpublished data). No other short normal subchron in a reverse chron has been identified during the Burdigalian (Gradstein et al. 2012); thus, its identification justifies the assignment of polarity zones MZs.
To extend the age model to older strata (i.e. the deposits of the Bílina local lake), we assumed that continuous deposition occurred above the main coal seam in LB432 and LB297. In LB432, we numbered the magnetozones and assigned them to the polarity chrons preceding the polarity zones/chrons identified in HK591. The depths of the reversals in HK591 (Matys Grygar et al. 2014) and LB432 (this study) were extrapolated to LB297 using the chemostratigraphic scheme shown in Figs 6 and 7. The dating of that core was then performed by linear extrapolation between the reversals.

The mean deposition rates in the cores were calculated from the thicknesses of the magnetic polarity zones and the durations of the polarity chrons according to ATNTS (Gradstein et al. 2012). The results are shown in Fig. 8 and Tab. 2. In cores HD50 and A24, we also used the position of C5Dr.1n. The resulting mean deposition rates in the newly studied cores range from 10 to $20 \mathrm{~cm} / \mathrm{ky}$, which are consistent with the estimates for the Libkovice Member (Matys Grygar et al. 2014), except for the slower net accumulation within C5Dr in the Bíline Mine area (LB297, LB432) that was previously described.

\section{Spectral analyses}

Drill core HK591, which is a reference core for the Libkovice Member (Matys Grygar et al. 2014), was subjected to a more detailed study of the Holešice Member and the lowermost part of the Libkovice Member (Fig. 9), particularly at depths of 244-175 m between the top of MZ-1 and the bottom of MZ1 (Fig. 8). We focused on the Fe/Al ratios to evaluate the regularity of siderite horizons in the Břeštany clays (ca. 200-187 m, Fig. 5). The spectral analyses showed a precession cycle at the bottom of MZ1 at a depth of $c a$. 

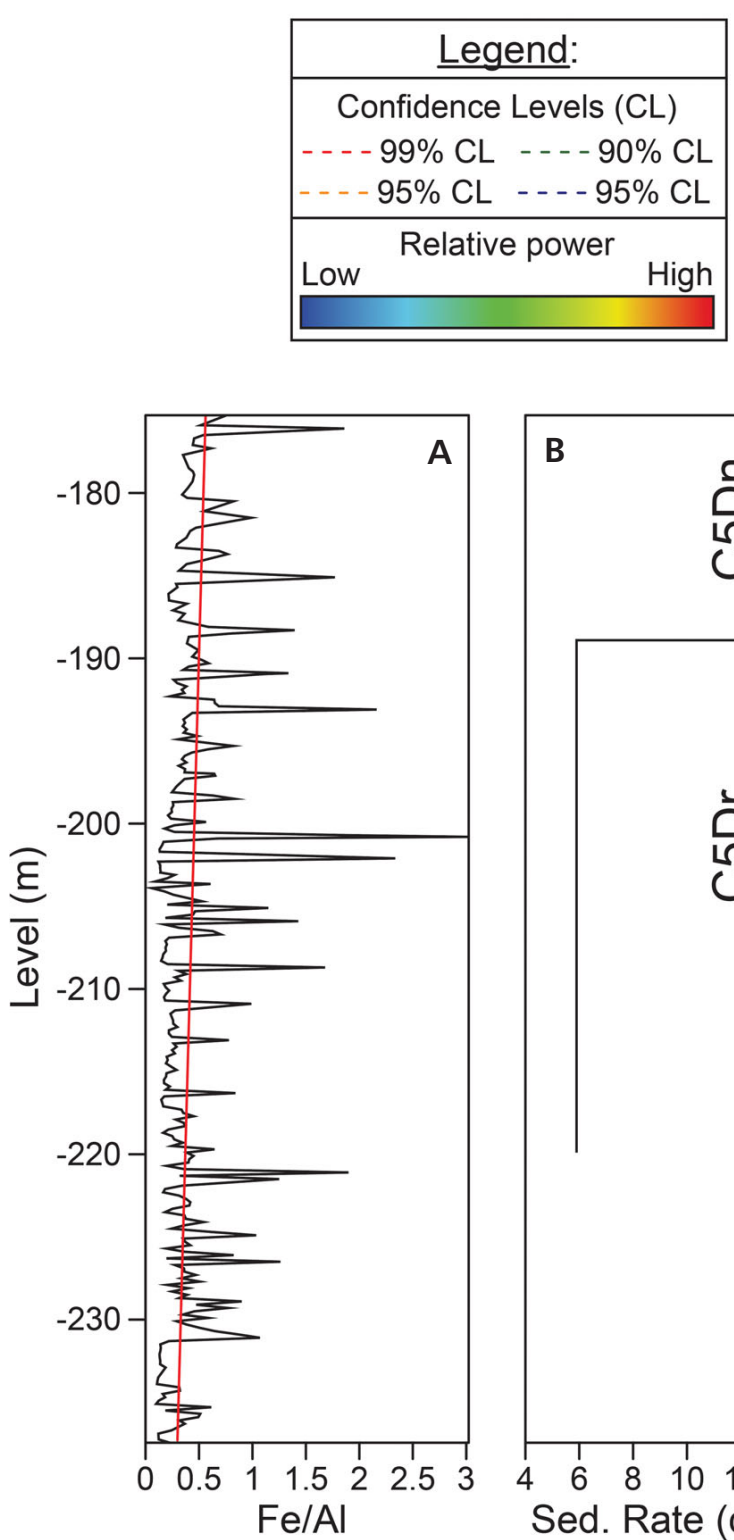

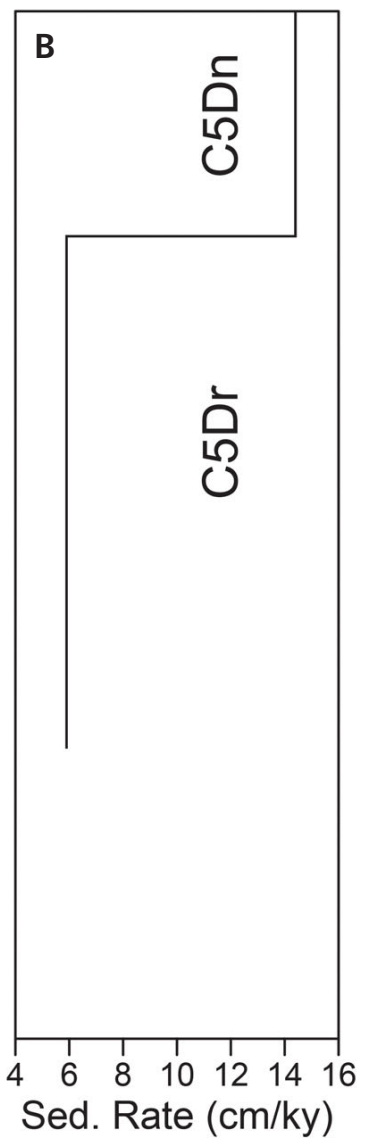

Figure 9. Spectral analyses of Fe/Al ratio in lower part of core HK591. • A - raw Fe/Al data (in black) with the long-term trend calculated using linear best-fit smoothing curve (in red). $\bullet \mathrm{B}$ - average sedimentation rate in chrons C5Dn and C5Dr. $\bullet \mathrm{C}-2 \pi$-multi-taper spectrum of the detrended Fe/Al series. Confidence levels were calculated using the Mann \& Lees (1996) approach modified applying a Tukey's endpoint rule to the fitting curve of the spectrum background (Meyers 2014). Main periods are labelled in metres. $\bullet$ D - amplitude spectrogram of the detrended Fe/Al series. Main periods are labelled in metres.

$180 \mathrm{~m}$ with a wavelength of $3.7 \mathrm{~m}$ (Fig. 9), which is plausibly consistent with the cycle duration (ca. $20 \mathrm{ky}$ ) and mean deposition rate $(14 \mathrm{~cm} / \mathrm{ky})$ in MZ1 (Tab. 2). The wavelength of the precession cycle decreases downward through $2.4 \mathrm{~m}$ at a depth of $c a .190 \mathrm{~m}$ to 1.3 or $1.1 \mathrm{~m}$ at a depth of $c a .210 \mathrm{~m}$ (Fig. 5, the Fe record), which we interpret to reflect a gradually changing deposition rate. Interestingly, the cycles with wavelengths of $3.7,2.4$, and $1.1 \mathrm{~m}$
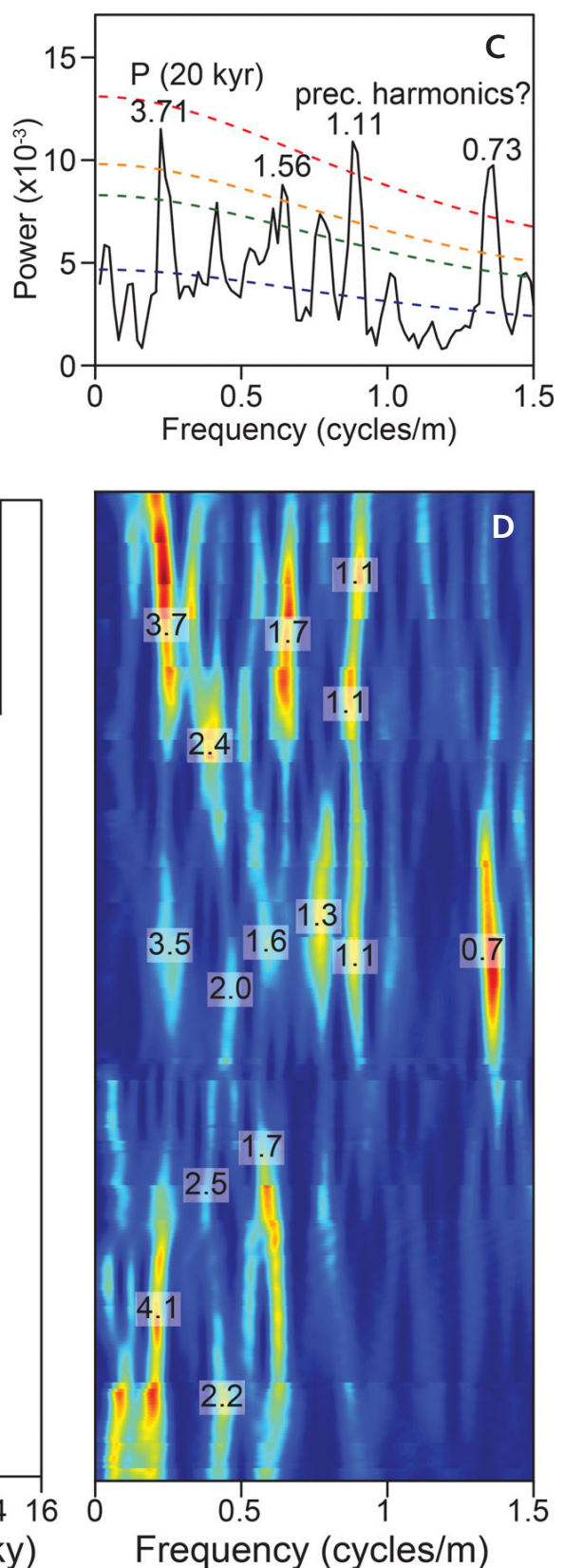

are accompanied by cycles with half wavelengths of 1.7 , 1.1 , and $0.7 \mathrm{~m}$, respectively. These shorter cycles could be attributed to precession harmonics, such as semiprecession, that affect low-latitude climates (Berger et al. 2006). This regularity is not obvious deeper in the core, i.e. below a depth of $210 \mathrm{~m}$. The spectral analyses of the K/Al ratios in the same core and depth intervals yielded similar results (not shown here). 
The deposition of heterolithic deltaic sediments in the HK591 core (BD units in Figs 3, 5) most likely caused the deposition rate of the entire polarity zone MZ0 to be smaller than that derived from the assignment of the 2.4and 1.3-m-scale periods to precession. This misfit is discussed below.

Drill core HD50 exhibited recurrent (cyclic) changes in its $\mathrm{K} / \mathrm{Al}$ depth profiles (Fig. 10). The most remarkable is the cycle with a wavelength of $c a .15 \mathrm{~m}$ at depths of 110-80 $\mathrm{m}$ and a wavelength $c a .25 \mathrm{~m}$ at depths of 70-20 m (Fig. 10). This cycle is coupled with $2.4 \mathrm{~m}$ and $3-5 \mathrm{~m}$ cycles, respectively (i.e. approximately 6:1) in both depth intervals, which is a similar ratio to that of short eccentricity and precession periods ( $c a .5: 1)$. The mean deposition rate in C5Dr.1r (depth 121-85 m) is $18 \mathrm{~cm} / \mathrm{ky}$ (Tab. 2); thus, the 15 and 2.4 m cycles should represent $c a .13$ and 82 ky, respectively (compared to the durations of precession and eccentricity of 20 and $100 \mathrm{ky}$, respectively). We consider the agreement of these calculated and theoretical durations to be plausible because the deposition rate in the cores was not constant (Tab. 2).

However, a considerable misfit in HD50 was found in the MZ1 zone (C5Dn) at depths of 85-40 m with a mean deposition rate of $14 \mathrm{~cm} / \mathrm{ky}$, according to magnetostratigraphy; in this case, the $27 \mathrm{~m}$ and $3 \mathrm{~m}$ cycles (Fig. 10) would represent nearly $200 \mathrm{ky}$ and $20 \mathrm{ky}$, respectively, of which the former is too long for short eccentricity and the cycle ratio is 9:1 instead of the 5:1 is too high as those expected for eccentricity and precession. There are three possible explanations for this misfit: a hiatus in the core, some orbital signal missing in the MZ1, or a factor other than orbital control causing the K/Al variations in the MZ1 unit. The hiatus hypothesis does not appear to be probable due to the similar overall deposition rates in the lower and upper parts of HD50 (Tab. 2) and the good correlation of the K depth profiles in all cores (Fig. 7). The two hypotheses of disturbed orbital control are discussed below.

\section{Discussion}

\section{Upgraded definition of the Holešice/Libkovice boundary}

The chemostratigraphic scheme that was previously published for the Libkovice Member (Matys Grygar \& Mach 2013a, b; Matys Grygar et al. 2014) is based on the assumption that these sediments were deposited in a single lake whose geochemistry was driven by basin-wide environmental changes. Extending that scheme to the basin periphery and to periods prior to the development of the basin-wide lake (the Holešice Member) is thus challenging because it is assumed that the basin-wide lake was preceded by several isolated water bodies (Mach et al. 2014). The previously described site-specific features in the sediment geochemistry (i.e. Fe/Al ratios, Sr patterns, and changes in the clay mineral assemblages in the early stages of clastic deposition above the main coal seam) support the model of unconnected depocentres in the early stages following the coal-forming period. However, we succeeded in identifying the Holešice/Libkovice boundary in HD50 and the Teplice-Ústí nad Labem area using the following criteria: (1) the CEC step to stable values $>0.1 \mathrm{mmol} \mathrm{Cu} / \mathrm{g}$ (Fig. 6), (2) the CEC step is within or immediately above a prominent $\mathrm{K} / \mathrm{Al}$ minimum (K2 in Fig. 7), and (3) the CEC step is located immediately above an inverse/normal magnetic polarity reversal (MZ0/MZ1 boundary in Fig. 8). The corresponding $\mathrm{K} / \mathrm{Al}$ minimum (K2) is surrounded by two nearly equally spaced K/Al minima, one of which is lower and is located near the top of the main coal seam (K1) and another which is higher and is associated with the $\mathrm{C} 1$ horizon (K3). The magnetic polarity reversal MZ0/MZ1 is a firm basis for our correlation scheme, as its record is independent of the hydrological connectivity of individual depocentres.

The successful identification of the Holešice/Libkovice boundary and K1 below that boundary in all of the studied depocentres supports our hypothesis that the lacustrine deposition in the Most Basin may reflect regional environmental/climate changes that might have controlled the $\mathrm{K}$ variations in the Libkovice Member. The identification of the Holešice/Libkovice boundary is a basis for the further evaluation of the sedimentary environment in the Most Basin in the following sections.

\section{Evolution of the local lake in the Bílina area}

Cores LB297 and LB432 include 100 and 120 m, respectively, of fine clastic deposits located between the main coal seam and the uppermost sands of the Bílina delta (labelled BR in Fig. 2B). The sediments in these two cores can be correlated using CEC and element logs (Figs 3, 7), assuming that the fine sandy sediments of the Bílina delta represent a rapid deposition event. The alteration between finer (clayey) and coarser (silty to fine sandy) sediments is similar in both cores due to their proximity (i.e. the distance between LB297 and LB432 is less than $1 \mathrm{~km}$ ).

The magnetic polarity dating of LB432 (this paper) and HK591 (Matys Grygar et al. 2014) and their chemostratigraphic correlation (described in the Results section) allowed an age model to be proposed for the Bílina local lake, Bílina delta, and Břeštany clay sediments in drill core LB297 (Fig. 11). The Bílina local lake deposits in the LB cores were formed between the end of the C5Er chron and the C5Dr chron. The Bílina local lake that was documented during coal prospecting is approximately $3 \mathrm{~km}$ wide (N-S) and at least 1-3 km long; however, its western 


\begin{tabular}{|c|}
\hline Legend: \\
\hline Confidence Levels $(\mathrm{CL})$ \\
$----99 \% \mathrm{CL}----90 \% \mathrm{CL}$ \\
$--95 \% \mathrm{CL}---95 \% \mathrm{CL}$ \\
\hline Relative power High \\
\hline
\end{tabular}

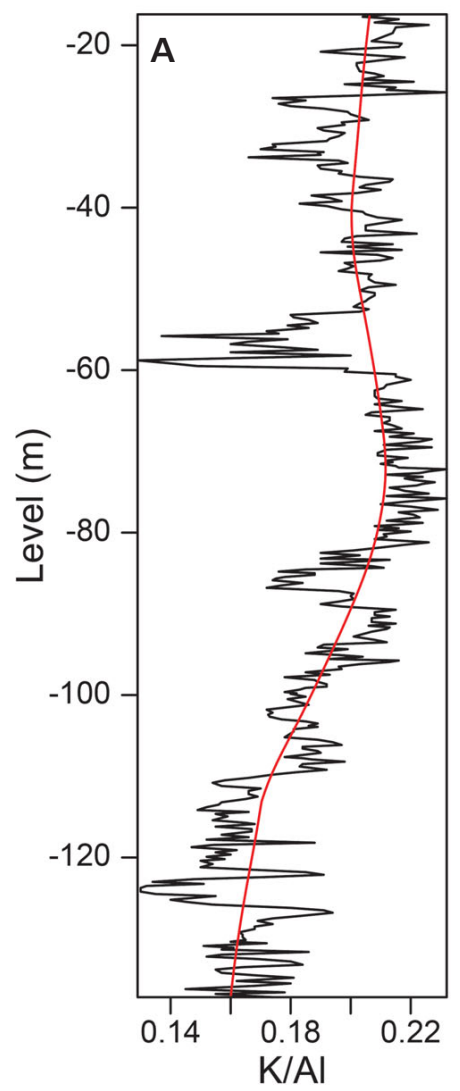

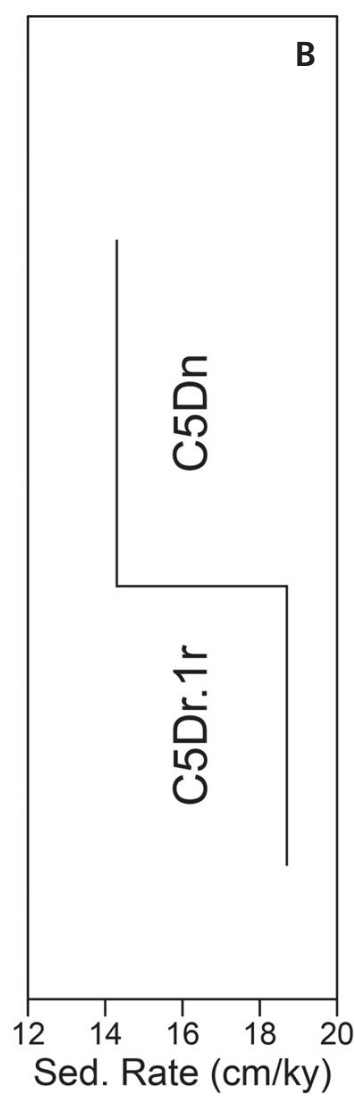

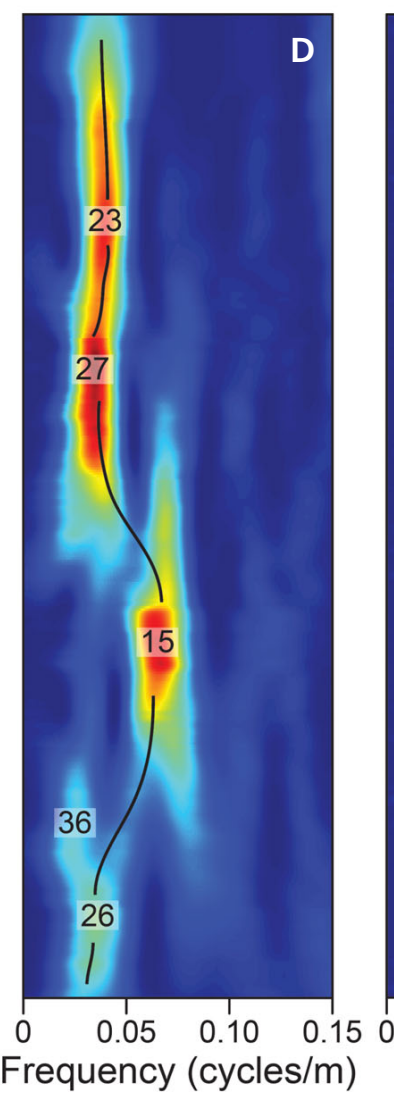

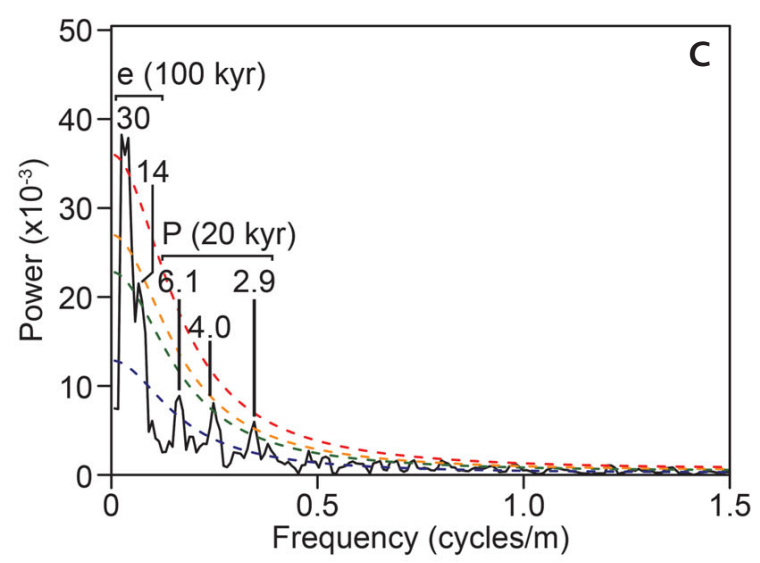

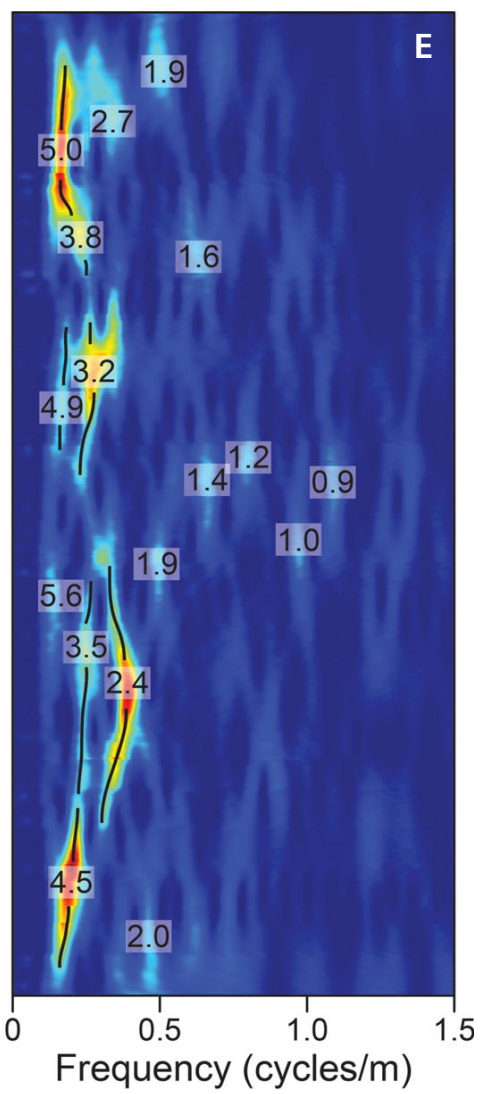

Figure 10. Spectral analyses of K/Al ratio in HD50. • A - raw K/Al data (in black) with the long-term trend calculated using a LOWESS smoothing with a coefficient of 0.4 (in red). $\bullet$ B - average sedimentation rate in chrons C5Dn and C5Dr.1r. $\bullet$ C -2 d-multi-taper spectrum of the detrended Fe/Al series. Confidence levels were calculated using the Mann \& Lees (1996) approach modified applying a Tukey's endpoint rule to the fitting curve of the spectrum background (Meyers 2014). Main periods are labelled in metres. $\bullet$ D, E - amplitude spectrogram of the detrended Fe/Al series. Main periods are labelled in metres.

edge is poorly constrained due to insufficiently detailed borehole documentation.

The most turbulent periods in the Bílina Mine area occurred during the C5Dr chron, in which the sandy/silty Bílina delta heteroliths were deposited and then covered by the Břeštany clay during the subsequent large (basin-wide) lake transgression. The deposition of the local lacustrine strata was uneven, with an apparently low net deposition rate of the Bílina delta sediment in the early part of C5Dr. The mean deposition rate during the entire C5Dr chron was 6-7 cm/ky (Tab. 2), in contrast, the Břeštany clay in the upper part of $\mathrm{C} 5 \mathrm{Dr}$ had a mean deposition rate of $10-15 \mathrm{~cm} / \mathrm{ky}$, based on the spacing of the siderite beds $(2-3 \mathrm{~m})$ and the assumption of their precession pacing 
(ca. $20 \mathrm{ky}$ ). We offer two possible explanations, which may be interrelated: either erosional hiatuses are likely to be present in the delta bodies or underlying local lake deposits exhausted the potential of the underlying peat compaction. In the Bílina delta area, peat compaction caused the stepwise progradation of clastic deposition (Dvořák \& Mach 1999, Mach et al. 2013). The termination of peat compaction by the early stages of clastic deposition was also demonstrated in Polish coal mines by Widera (2016b). The assumption of a low net deposition rate during C5Dr in the Bílina Mine area is also supported by the fact that the overall thickness of the deposits of MZ0 in core HD50 is greater than that in LB297 (Fig. 8); although the lower boundary of MZ0 was identified in HD50, its deposits are thicker than the entire MZ0 in the Bílina Mine area.

The timing of the uppermost Bílina delta heteroliths is constrained between the top of C5En (18.056 Ma) in HK591 and LB432 and the age of $17.7 \mathrm{Ma}$, which was estimated using the top of C5Dr and the duration of the Břeštany clay deposition (Fig. 5).

\section{Deposition in the Most area}

All of the drill cores obtained in the Most area only covered the lowermost part of the clastic strata above the main coal seam, because coal prospecting in that area ended before we started our work. Drill core AL405 was obtained from the second overburden mining bench of the VČSA Mine (Fig. 1). It included $72 \mathrm{~m}$ of low-CEC, clayey strata with high $\mathrm{Sr}$ contents, which are typical features of the Holešice Member in the Bílina Mine area. The K/Al ratios in AL405 did not allow for correlation with the other cores because the record was apparently too short to obtain a sufficient number of K minima (Matys Grygar 2010). We interpret the relatively thick kaolinite-rich strata in AL405 to represent a distal part of the Bílina delta, which could constrain the size of the Bílina local lake, which was probably in its terminal stage before the large (basin-wide) transgression.

The main coal seam in cores HY440 and HO880 from the northern foreland of the Vršany Mine is covered by at least 30 and $50 \mathrm{~m}$, respectively, of high-CEC clayey strata with high Sr contents representing broad featureless maxima. We interpret the difference between the CEC values of these two cores and those in AL405 to reflect deposition in separate or otherwise distinct water bodies with different water residence times. The Vršany Mine area was not influenced by the Bílina lake/delta as much as the area of the VČSA Mine was. On the other hand, the fine deposits of the central river above the main coal seam (CR in Fig. 2A) have higher CEC values than the Bílina river deposits in the Libouš Mine area (lowermost clastic strata in DO546; Fig. 6).

\section{Deposition in Háj u Duchcova}

Core HD50 yielded uniform grey silty clays that occasionally contained irregularly spaced beds with elevated siderite contents and trace fossils (Planolites montanus). The $\mathrm{K}$ (or $\mathrm{K} / \mathrm{Al}$ ) and $\mathrm{CEC}$ depth profiles allow the Holešice/Libkovice boundary to be identified (Fig. 3) and the magnetic polarity zones to be assigned to chrons (Fig. 8). However, neither the Bílina delta heteroliths nor siderite beds similar to those in the Břeštany clay were identified in HD50. The dated record from this core is shown in Fig. 12. The mean deposition rates were $18 \mathrm{~cm} / \mathrm{ky}$ during C5Dr.1r and $15 \mathrm{~cm} / \mathrm{ky}$ during C5Dn (Tab. 2). The downward extrapolation of these values gives an estimate of $17.8 \mathrm{Ma}$ for the end of coal formation, which is similar to the estimate obtained for the uppermost Bílina delta heteroliths in LB297 in the Bílina Mine area. We thus interpret the deposits in core HD50 that are located immediately above the main coal seam to represent the distal part of the final stages of the Bílina delta, which laterally correspond to the lower part of HK591 and all of AL405.

\section{Deposition in the Teplice-Ústí nad Labem area}

Three cores were retrieved between Teplice and Ústí nad Labem. In two of the cores, A24 and ZU5A, magnetic polarity analyses were successfully performed (Fig. 8). From the top of the coal seam to a depth of $c a .80 \mathrm{~m}$ in ZU5A, the clay strata are occasionally finely laminated, similar to the fine Holešice sediments in the Bílina Mine area. The overlying strata of the Libkovice Member are massive and contain trace fossils of Planolites montanus. The sediment in core A26 was similar but lacked most of the chemostratigraphic variations that were found in A24 and ZU5A. The first few metres of sediments immediately above the main coal seam in all three drill cores were disturbed by a roof fall, because those cores entered locations of historical deep coal mining. However, we identified the minimum K1 (Fig. 7) and excursions of C5Dr.1n in the lowermost parts of A24 (Fig. 8), which proves that it records similar timing of the termination of coal formation as in the Háj u Duchcova area.

\section{Comparison with the Libouš Mine area}

The previous study of cores from the Libouš Mine area showed an abrupt $\mathrm{K}$ minimum, which was denoted as $\mathrm{K} 1$, immediately above the main coal seam (core DO546 in Figs 6,7). In addition, the CEC depth profiles in the lowermost part of the clastics above the main coal seam in the Libouš Mine area and the Teplice-Ústí nad Labem cores ZU5A and A24 from the opposite part of the Most Basin 
Figure 11. The age model for sediments above the main coal seam in the Bílina Mine area in core LB297. The magnetozone boundaries were extrapolated from HK591 and LB432. Abbreviations: $\mathrm{BC}-$ Břeštany clay; BD - Bílina delta sands; DC - dark clays.

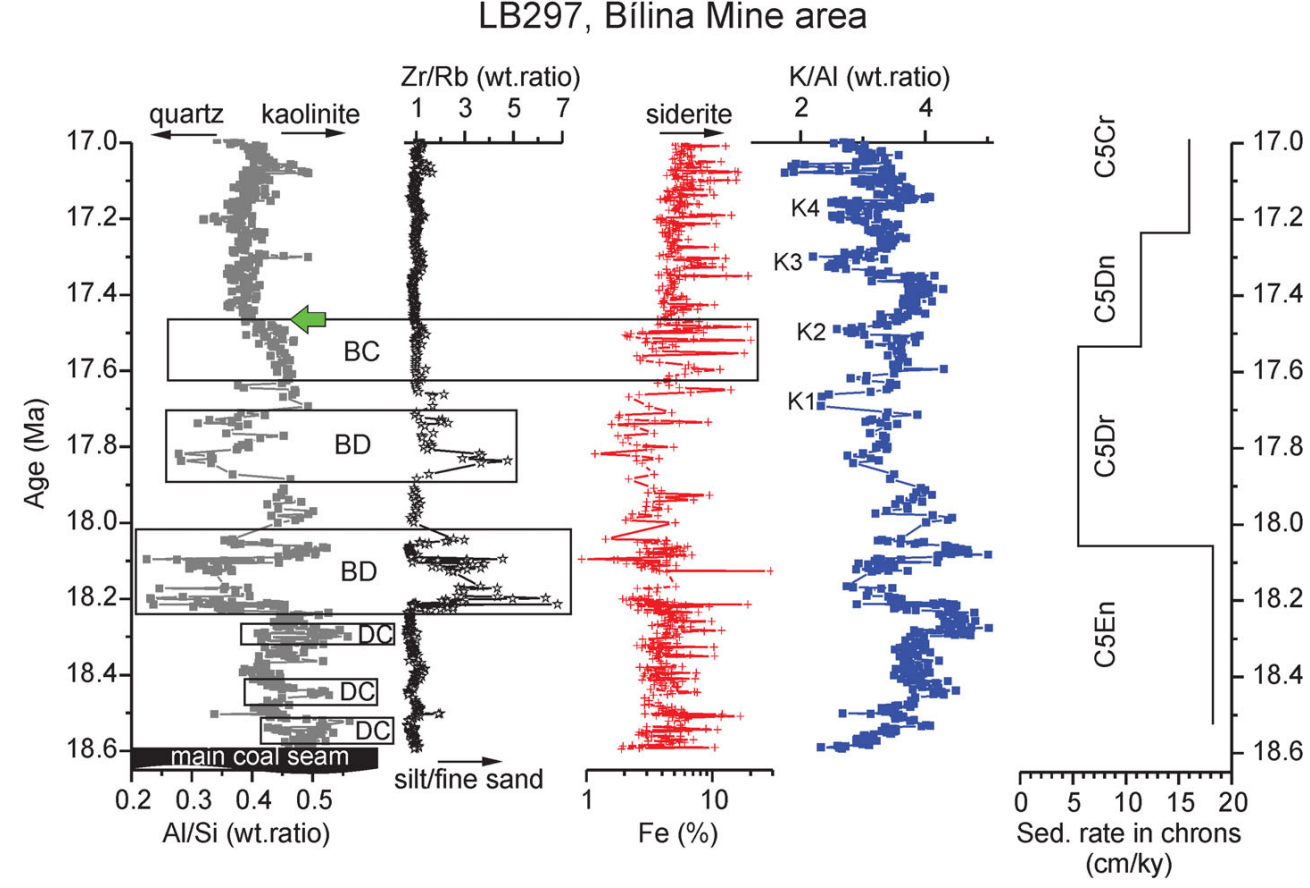

are very similar (Fig. 3). We interpret these similarities to reflect the same timing of the termination of coal formation in the Libouš Mine area as in Háj u Duchcova and the Teplice-Ústí nad Labem area.

\section{Possible causes of basin-wide lake transgression}

The climate before the MCO was relatively dynamic. The Antarctic ice sheet (AIS) became unstable $c a$. 17.8 Ma, and its extent decreased and varied until $16 \mathrm{Ma}$ (Levy et al. 2016). The disruption of the carbon cycle before the MCO was started by the progressive shift in benthic $\delta^{13} \mathrm{C}$ that started in the C5Dr.1r subchron (Kochhann et al. 2016), which was coeval with the Břeštany clay deposition during the major lake transgression in the Most Basin. According to the detailed climate reconstruction presented by Utescher et al. (2012), NW Europe experienced an increase in the mean annual precipitation (without an increasing mean annual temperature) from $c a$. 17.8 Ma to its Miocene maximum ca. 17.0 Ma. The basin-wide lake in the Most Basin thus formed under climatically favourable conditions of enhanced precipitation, which we assume was controlled by global climate change.

The possibility of tectonic control over depositional sequences is expected in sedimentary basins (Uličný et al. 2014, Valero et al. 2017). Rajchl et al. (2009) assumed that the peat accumulation in the Most Basin was terminated by increased tectonic subsidence and a deposition rate that was several times larger during clastic deposition; how- ever, they did not present a reliable age model that supported their conclusion. The magnetostratigraphy-based mean deposition rates (Tab. 2) do not vary dramatically over time, except for MZ0 in the Bílina Mine area; however, this was a relatively local phenomenon with respect to deposition in Háj u Duchcova (HD50). The deposition rates in the early stages of clastic deposition above the main coal seam were similar regardless of the actual time and depositional area. We attribute this to peat compaction driven by the overlying clastics, which inevitably contributed to the final subsidence of the basin floor. The importance of peat compaction to the local architecture of coal-basin fill is well known (see Geological Setting for references), but the broader geographic impact of peat compaction can also be expected to play a role. For example, the compaction of underlying peat has substantially contributed to recent basin floor subsidence in the Rhine delta, where the tectonic- and peat compaction-driven contributions to the net basin-floor subsidence during the Holocene are comparable (Van Asselen 2011). We thus hypothesize that subsidence-driven peat accumulation in the Most Basin was terminated by the climatically enhanced clastic input at approximately $17.8 \mathrm{Ma}$ and was not exclusively controlled by tectonics. The E-W-oriented Bílina fault (Rajchl et al. 2008) south of the Bílina Mine probably caused the largest local lake in this part of the basin to form nearly a million years earlier.

To judge the hypothesis of the tectonic trigger of the peatland-to-lake transition proposed by Rajchl et al. (2009), we can estimate the duration of the peat accumulation period in the Most Basin. Fejfar et al. (2003) assigned 


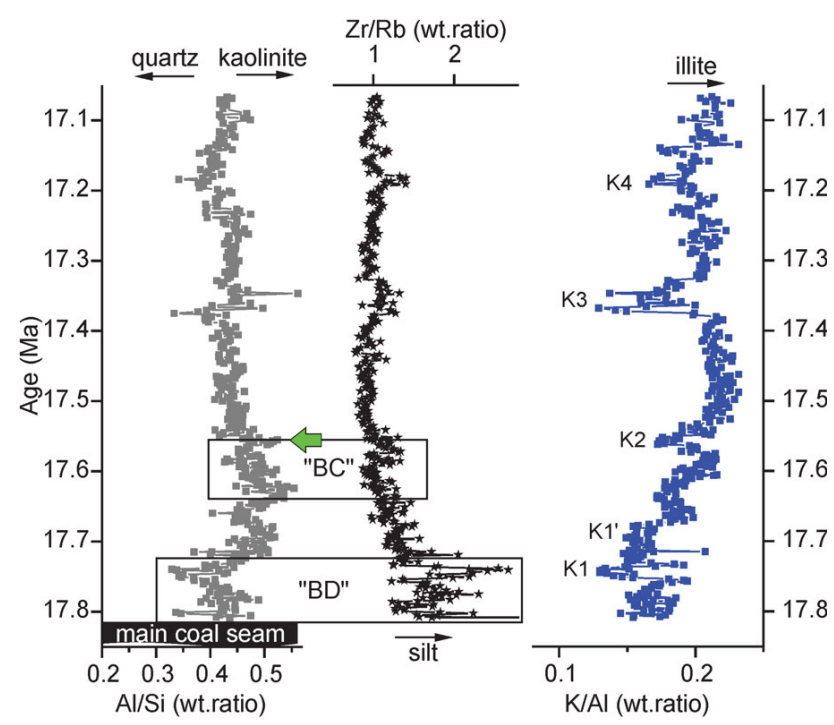

Figure 12. Age model for the HD50 core based on the C5Dr.n1, $\mathrm{MZ0/MZ1,} \mathrm{and} \mathrm{extrapolated} \mathrm{age} \mathrm{for} \mathrm{K3.} \mathrm{Abbreviations} \mathrm{"BC"} \mathrm{and} \mathrm{"BD"}$ stand for lateral analogues of Břeštay clay and Bílina delta sands.

palaeontological remains at the base of the main coal seam to the European mammal zone MN3, which started at 20.5 Ma (Schlunegger et al. 2007). The peat accumulation would thus have lasted less than 2.7 My. The main coal seam in the Most Basin is typically 30-35 m thick, but this could have represented a $c a$. 220-m-thick layer of peat prior to its diagenetic compaction, for which a 7:1 ratio was found by Hurník (1972). The peat deposition rate would thus be larger than $8 \mathrm{~cm} / \mathrm{ky}$, which is similar to the rate of the subsequent clastic deposition (Tab. 2). Although those estimates are rather coarse and represent a maximum duration and minimum deposition rate of the peat accumulation, they do not support tectonically enhanced subsidence as a cause of the basin-wide lake transgression.

The spectral analyses of HK591 and HD50 confirmed the orbital control over sediment geochemistry during the basin-wide lake transgression (Figs 9, 10), which is similar to that observed in the middle and upper parts of the Libkovice Member deposits (Matys Grygar et al. 2014). However, we repeatedly found discrepancies between the magnetostratigraphy- and cyclostratigraphy-derived estimates of the mean deposition rates around the $\mathrm{K} 3 \mathrm{~min}$ imum, described in the Results for the HD50 core. The assignment of the polarity zone MZ1 to chron C5Dn, which is possible in all currently available records (Fig. 8), produces a mean deposition rate of $15 \mathrm{~cm} / \mathrm{ky}$ (Tab. 2). Then, the wavelength of $c a .27 \mathrm{~m}$ found in that interval in HD50 (Fig. 10, at a depth of 60-70 m) would require a cycle duration of $180 \mathrm{ky}$, i.e. ca. twice as long as a short eccentricity, while the wavelength of $3.2 \mathrm{~m}$ (the second prominent cycle at a depth $c a .60 \mathrm{~m}$ ) would imply a cycle duration of $21 \mathrm{ky}$, which is attributable to precession. This discrepancy can thus be interpreted to reflect the missing record of one short eccentricity cycle in the sedimentary record. Further analysis of the Most Basin deposits will be necessary to support the "missing eccentricity cycle" explanation, but we prefer this conclusion based on all accessible facts.

Another hypothetical explanation for the observed discrepancy in HD50 could be another reason than the orbital control of the long-term $\mathrm{K}$ variation in the Most Basin. The interpolated age estimate for the $\mathrm{K} 3$ minimum of $c a$. 17.35 Ma (ATNTS2012 timescale) is within the age interval of the Kumburk and Zebín lava flows in the eastern part of the České Středohoři Mts. (Cajz et al. 2009). The K3 minimum is associated with the $\mathrm{C} 1$ crandallite horizon (Fig. 6), for which a volcanic trigger has been proposed (Novák et al. 1993). We could thus hypothetically attribute the K3 minimum to a volcano-tectonic control that intermittently overwrote the climatic signal in the Most Basin sedimentary record. However, there is currently no evidence of the occurrence of such a massive volcano-tectonic event in the Most Basin catchment that could have produced not only a few cm-thick crandallite horizons but also a few metres thick layer of clastic sediments with an element composition that is markedly changed enough to produce the K3 minimum.

The most robust verification that the termination of peat accumulation in the Most Basin was caused by climate change and not by local tectonics would be a comparison of our results with similarly detailed and firmly dated records from other sites. We are not aware of the existence of such records in other basins; however, we believe that the period of time immediately preceding the $\mathrm{MCO}$ will be studied further and that this comparison will soon be possible. The period immediately preceding the MCO has recently attracted the attention of several researchers (Kochhann et al. 2016, Levy et al. 2016). This interest is likely to persist at least unless the triggers of the MCO can be recognized, the possible uncertainty of the ATNTS2012 timescale (Kochhann et al. 2016) can be clarified, and the Burdigalian stratigraphy of other large depocentres in the ECRIS can be corroborated (Reichenbacher et al. 2013).

\section{Conclusions}

The clastic sediments above the main coal seam of the Most Formation record changes in magnetic polarity and the environment in the lake catchment that were mostly controlled by orbital forcing. This combination makes the Most Formation a valuable environmental archive of the period preceding the major warming in the Miocene. The local lake in the Bílina Mine area existed for more than 0.5 My between 18.5 and $18.0 \mathrm{Ma}$ and was surrounded by vast peatlands. This lake underwent a transitional phase between 18.0 and 17.7 Ma that resulted in the expansion of 
the local lake and the intermittent decreases of the clastic deposition rate in the Bílina Mine area. After ca. 17.8 Ma, the basin-wide lake formed; this occurred coevally throughout all of the study sites in the Most Basin within the accuracy of the age model. This change terminated peat accumulation in the Most Basin, and the compaction of peat by fluvial clastics, rather than tectonics, caused the basin floor subsidence that made it possible to record the effects of climate change. The 17.8 Ma event coincided with the melting of the Antarctic ice sheet before the Miocene climatic optimum, which was dated by Levy et al. (2016), and the start of increasing mean annual precipitation in Europe (Utescher et al. 2012). Further comparisons with other independent environmental archives are necessary to confirm that the evolution of the Most Basin was controlled by climate and not by tectonics.

\section{Acknowledgement}

Martin Faměra, Monika Maříková, and Petr Vorm (Institute of Inorganic Chemistry) assisted with sampling of drill cores for chemical analyses, Monina Maříková and Petr Vorm performed most laboratory analyses (XRF and CEC). Kristýna Č́ižková and Šimon Kdýr (Institute of Geology) assisted in sampling of drill cores and their palaeomagnetic analysis (Institute of Geology, AS CR). Palivový Kombinát Ústí, s.p., kindly permitted to sample drill cores A24, A26, and ZU5A. This work would not be possible without the access to drill cores LB432 and HD50 provided generously by VODAMIN project coordinated by Palivový Kombinát Ústí, s.p. Drill core LB297 was kindly provided by North Bohemian Mines. All laboratory analyses (XRF, CEC, and palaeomagnetism) and manuscript preparation were funded by the Czech Science Foundation (GAC̆R 16-00800S). The final shape of the manuscript was improved by two reviewers (O. Mandic and Anonymous Reviewer).

\section{References}

Berger, A., Loutre, M.F. \& Mélice, J.L. 2006. Equatorial insolation: from precession harmonics to eccentricity frequencies. Climate of the Past 2, 131-136. DOI 10.5194/cp-2-131-2006

Bouchez, J., Gaillardet, J., France-Lanord, C., Maurice, L. \& Dutra-MaiA, P. 2011. Grain size control of river suspended sediment geochemistry: Clues from Amazon River depth profiles. Geochemistry Geophysics Geosystems 12(3), Q03008. DOI 10.1029/2010GC003380

Cajz, V., Rapprich, V., Schnabl, P. \& Pécskay, Z. 2009. Návrh litostratigrafie neovulkanitů východočeské oblasti (A proposal on lithostratigraphy of Cenozoic volcanic rocks in Eastern Bohemia). Zprávy o geologických výzkumech v roce 2008, 9-15.

Clift, P.D., Wan, S.M. \& BluszTajn, J. 2014. Reconstructing chemical weathering, physical erosion and monsoon intensity since $25 \mathrm{Ma}$ in the northern South China Sea: A review of competing proxies. Earth-Science Reviews 130, 86-102.

DOI 10.1016/j.earscirev.2014.01.002

DiLL, H.D. 2001. The geology of aluminium phosphates and sulphates of the alunite group minerals: a review. Earth-Science Reviews 53(1-2), 35-93.

DOI 10.1016/S0012-8252(00)00035-0

DvořÁ, Z. \& МАCH, K. 1999. Deltaic deposits in the NorthBohemian Brown Coal Basin and their documentation. Acta Universitatis Carolinae Geologica 43(4), 633-641.

Elznic, A., ČAdková, Z. \& Dušek, P. 1998. Paleogeografie terciérních sedimentů severočeské pánve, Sborník geologických věd, Geologie 48, 19-46.

FeJfar, O., Dvořák, Z. \& Kadlecová, E. 2003. New record of early Miocene (MN3a) mammals in the open brown coal pit Merkur, North Bohemia, Czech Republic, 163-182. In ReumER, J.W.F. \& Wessels, W. (eds) Distribution and migration of tertiary mammals in Eurasia. A volume in honour of Hans de Bruijn. Deinsea 10.

Gradstein, F.M., OgG, J.G., Schmitz, M.D. \& OGG, G.M. 2012. The Geologic Time Scale 2012. Elsevier BV, Amsterdam.

Grygar, T., Kadlec, J., Žigová, A., Mihaljevič, M., Nekutová, T., LOJKA, R. \& SVĚTLík, I. 2009. Chemostratigraphic correlation of sediments containing expandable clay minerals based on ion exchange with $\mathrm{Cu}$ (II) complex with triethylenetetramine. Clays and Clay Minerals 57(2), 168-182.

DOI 10.1346/CCMN.2009.0570204

HuRNí, S. 1972. Koeficient sednutí některých sedimentů v Severočeské hnědouhelné pánvi. Časopis pro mineralogii a geologii 17(4), 365-372.

IEd, I.M., HolcovÁ, K. \& ABd-Elshafy, E. 2011. Biostratigraphy and paleoecology of the Burdigalian-Serravallian sediments in Wadi Sudr (Gulf of Suez, Egypt): comparison with the Central Paratethys evolution. Geologica Carpathica 62(3), 233-249. DOI 10.2478/v10096-011-0019-6

Jones, A.F., Macklin, M.G. \& Brewer, P.A. 2012. A geochemical record of flooding on the upper River Severn, UK, during the last 3750 years. Geomorphology 179, 89-105.

DOI 10.1016/j.geomorph.2012.08.003

KiRSChVINK, J.L. 1980. The least-squares line and plane and the analysis of palaeomagnetic data. Geophysical Journal of the Royal Astronomical Society 62(3), 699-718. DOI 10.1111/j.1365-246X.1980.tb02601.x

Kochhann, K.G.D., Holbourn, A., Kuhnt, W., Channell, J.E.T., Lyle, M., Shackford, J.K., Wilkens, R.H. \& Andersen, N. 2016. Eccentricity pacing of eastern equatorial Pacific carbonate dissolution cycles during the Miocene Climatic Optimum. Paleoceanography 31(9), 1176-1192. DOI 10.1002/2016PA002988

Kovar-Eder, J., Kvaček, Z. \& Meller, B. 2001. Comparing Early to Middle Miocene floras and probable vegetation types of Oberdorf N Voitsberg (Austria), Bohemia (Czech Republic), and Wackersdorf (Germany). Review of Palaeobotany and Palynology 114(1-2), 83-125. DOI 10.1016/S0034-6667(00)00070-1

LEVY, R. et al. 2016. Antarctic ice sheet sensitivity to atmospheric $\mathrm{CO}_{2}$ variations in the early to mid-Miocene. Proceedings of 
National Academy of Sciences 113(13), 3453-3458. DOI 10.1073/pnas.1516030113

MACH, K. 2003. Genesis of large scale syndepositional deformations of main coal seam-Miocene Bílina delta, Most Basin, Czech Republic. 83 pp. Ph.D. thesis, Charles University, Prague, Czech Republic.

Mach, K., SÝKorová, I., KonZalová, M. \& Opluštil, S. 2013. Effect of relative lake-level changes in mire-lake system on the petrographic and floristic compositions of a coal seam, in the Most Basin (Miocene), Czech Republic. International Journal of Coal Geology 105, 120-136.

DOI 10.1016/j.coal.2012.10.011

Mach, K., Teodoridis, V., Matys Grygar, T., Kvaček, Z., Suhr, P. \& StandKe, G. 2014. An evaluation of paleogeography and paleoecology in the Most Basin (Czech Republic) and Saxony (Germany) from the late Oligocene to the early Miocene. Neues Jahrbuch für Geologie und Paläontologie, Abhandlungen 272/1, 13-45. DOI 10.1127/0077-7749/2014/0395

MANN, M.E. \& LEES, J.M. 1996. Robust estimation of background noise and signal detection in climatic time series. Climatic Change 33(3), 409-445. DOI 10.1007/BF00142586

Martinez, M., Deconinck, J.F., Pellenard, P., Reboulet, S. \& Riquier, L. 2013. Astrochronology of the Valanginian Stage from reference sections (Vocontian Basin, France) and palaeoenvironmental implications for the Weissert Event. Palaeogeography, Palaeoclimatology, Palaeoecology 376, 91-102. DOI 10.1016/j.palaeo.2013.02.021

Martinez, M., Deconinck, J.F., Pellenard, P., Riquier, L., ComPany, M., Reboulet, S. \& Moiroud, M. 2015. Astrochronology of the Valanginian-Hauterivian stages (Early Cretaceous): Chronological relationships between the Paraná-Etendeka large igneous province and the Weissert and the Faraoni events. Global and Planetary Change 131, 158-173. DOI 10.1016/j.gloplacha.2015.06.001

Matys Grygar, T. 2010. Geochemical analysis of drill cores AL405 and SP257 and their comparison with LB297 (Ko-8). Research report for North Bohemian Mines.

Matys Grygar, T. \& MACH, K. 2013a. Chemostratigrafie miocenních sedimentů mostecké pánve (Chemostratigraphy of Miocene sediments in Most Basin). Zprávy o geologických výzkumech v roce 2012, 26-29.

Matys Grygar, T. \& Mach, K. 2013b. Regional chemostratigraphic key horizons in the macrofossil-barren siliciclastic lower Miocene lacustrine sediments (Most Basin, Eger Graben, Czech Republic), Bulletin of Geosciences 88(3), 557-571. DOI 10.3140/bull.geosci.1372

Matys Grygar, T. \& Popelka, J. 2016. Revisiting geochemical methods of distinguishing natural concentrations and pollution by risk elements in fluvial sediments. Journal of Geochemical Exploration 170, 39-57. DOI 10.1016/j.gexplo.2016.08.003

Matys Grygar, T., Elznicová, J., Kiss, T. \& Smith, H.G. 2016. Using sedimentary archives to reconstruct pollution history and sediment provenance: The Ohře River, Czech Republic. Catena 144, 109-129. DOI 10.1016/j.catena.2016.05.004
Matys Grygar, T., Mach, K., Pruner, P., Schnabl, P., Laurin, J. \& Martinez, M. 2014. A lacustrine record of the early stage of the Miocene Climatic Optimum in Central Europe from the Most Basin, Ohře (Eger) Graben, Czech Republic. Geological Magazine 151(6), 1013-1033. DOI $10.1017 /$ S0016756813001052

Meier, L.P. \& Kahr, G. 1999. Determination of the cation exchange capacity (CEC) of clay minerals using the complexes of copper (II) ion with triethylenetetramine and tetraethylenepentamine, Clays and Clay Minerals 47(3), 386-388. DOI 10.1346/CCMN.1999.0470315

MeYers, S.R. 2014. Astrochron: An R Package for Astrochronology.

http:/cran.r-project.org/package $=$ astrochron.

Novák, F., Pekárková, R. \& Ševcư, J. 1993. Barium rich crandallite from the Nástup Tušimice quarry (North-Bohemian Brown-Coal Basin, Věstník Českého geologického ústavu 68, 53-57.

Novotný, T. \& MACH, K. 2016. Liboušský aluviální systém ovlivněný synsedimentární kompakcí rašeliny (spodní miocén, mostecká pánev). Zpravodaj Hnědé uhli 2, 3-12.

PEŠEK, J. et al. 2010. Terciérni pánve a ložiska hnědého uhlí České republiky (Tertiary Basins and Soft Coal Seams of the Czech Republic). 438 pp. Czech Geological Survey, Prague.

RAJChl, M. \& UliČnÝ, D. 2005: Depositional record of an avulsive fluvial system controlled by peat compaction (Neogene, Most Basin, Czech Republic). Sedimentology 52(3), 601-625. DOI 10.1111/j.1365-3091.2005.00691.x

RAJChl, M., UličnÝ, D., GRYGaR, R. \& MACH, K. 2009. Evolution of basin architecture in an incipient continental rift: the Cenozoic Most Basin, Eger Graben (Central Europe). Basin Research 21(3), 269-294.

DOI 10.1111/j.1365-2117.2008.00393.x

RAJCHL, M., ULIČNÝ, D. \& MACH, K. 2008. Interplay between tectonics and compaction in a rift-margin, lacustrine delta system: Miocene of the Eger Graben, Czech Republic. Sedimentology 55(5), 1419-1447.

DOI 10.1111/j.1365-3091.2008.00951.x

Reichenbacher, B., Krijgsman, W., Lataster, Y., Pippèrr, M., Van BaAk, C.G.C., Chang, L., Kälin, D., Jost, J., Doppler, G., Jung, D., Prieto, J., Abdul Aziz, H., Böhme, M., Garnish, J., Kirscher, U. \& Bachtadse, V. 2013. A new magnetostratigraphic framework for the Lower Miocene (Burdigalian/Ottnangian, Karpatian) in the North Alpine Foreland Basin. Swiss Journal of Geosciences 106(2), 309-334. DOI 10.1007/s00015-013-0142-8

Rudnick, R. \& GAO, S. 2003. Composition of the continental crust, 1-64. In Rudnick, R.L., Holland, H.D. \& TuReKian, K.K. (eds) The Crust. Treatise on Geochemistry 3. Elsevier-Pergamon, Oxford.

Schlunegger, F., Rieke-ZApP, D. \& Ramseyer, K. 2007. Possible environmental effects on the evolution of the Alps-Molasse Basin system. Swiss Journal of Geosciences 100(3), 383-405. DOI 10.1007/s00015-007-1238-9

SLOUPSKÁ, M. 1985. Nerostné složeni tercierních sedimentů SHR. Manuscript. VÚHU Most, Most. 
TANer, M.T. 2003. Attributes Revisited, Technical Publication. Houston, Texas: Rock Solid Images, Inc.

http://rocksolidimages.com/pdf/attrib_revisited.htm

Thomson, D.J. 1982. Spectrum estimation and harmonic analysis. Proceedings of the IEEE 70, 1055-1096.

DOI 10.1109/PROC.1982.12433

Thomson, D.J. 1990. Quadratic-inverse spectrum estimates - applications to paleoclimatology. Philosophical Transactions of the Royal Society of London Series A - Mathematical Physical and Engineering Sciences 332(1627), 539-597. DOI 10.1098/rsta.1990.0130

UličNÝ, D., LAURIN, J. \& ČECH, S. 2008. Controls on clastic sequence geometries in a shallow-marine, transtensional basin: The Bohemian Cretaceous Basin, Czech Republic. Sedimentology 56(4), 1077-1114. DOI 10.1111/j.1365-3091.2008.01021.x

UličnÝ, D., Jarvis, I., Gröcke, D.R., Čech, S., Laurin, J., Olde, K., Trabucho-Alexandre, J., Švábenická, L. \& PedentCHOUK, N. 2014. A high-resolution carbon-isotope record of the Turonian stage correlated to a siliciclastic basin fill: Implications for mid-Cretaceous sea-level change. Palaeogeography, Palaeoclimatology, Palaeoecology 405, 42-58. DOI 10.1016/j.palaeo.2014.03.033

Utescher, T., Ashraf, A.R., Dreist, A., Dybkjer, K., Mosbrugger, V., Pross, J. \& Wilder, V. 2012. Variability of Neogene Continental Climates in Northwest Europe - A Detailed Study Based on Microfloras. Turkish Journal of Earth Sciences 21, 289-314.

Valero, L., Huerta, P., Garcés, M., Armenteros, I., Beamud, E. \& GÓMEZ-PACCARD, M. 2017. Linking sedimentation rates and large-scale architecture for facies prediction in nonmarine basins (Paleogene, Almazán Basin, Spain), Basin Research 29(S1), 213-232. DOI 10.1111/bre.12145

VAN AsSELEN, S. 2011. The contribution of peat compaction to total basin subsidence: implications for the provision of accommodation space in organic-rich deltas. Basin Research 23(2), 239-255. DOI 10.1111/j.1365-2117.2010.00482.x

Van Asselen, S., Stouthamer, E. \& Van Asch, T.W.J. 2009. Effects of peat compaction on delta evolution: A review on processes, responses, measuring and modelling. Earth-Science Reviews 92(1-2), 35-51.

DOI 10.1016/j.earscirev.2008.11.001

WidERA, M. 2015. Compaction of lignite: a review of methods and results. Acta Geologica Polonica 65(3), 367-378.

DOI 10.1515/agp-2015-0016

WIDERA, M. 2016a. Depositional environments of overbank sedimentation in the lignite-bearing Grey Clays Member: New evidence from Middle Miocene deposits of central Poland. Sedimentary Geology 335, 150-165.

DOI 10.1016/j.sedgeo.2016.02.013

WidERA, M. 2016b. Characteristics and origin of deformation structures within lignite seams - a case study from Polish opencast mines. Geological Quarterly 60(1), 181-191. DOI $10.7306 / g q .1268$

Zachos, J., Pagani, M., Sloan, L., Thomas, E. \& Billups, K. 2001. Trends, rhythms, and aberrations in global climate 65 Ma to present. Science 292(5517), 686-693.

DOI 10.1126/science. 1059412

ZiEgLER, P.A. \& DĖZES, P. 2007. Cenozoic uplift of Variscan Massifs in the Alpine foreland: Timing and controlling mechanisms. Global and Planetary Change 58(1-4), 237-269. DOI 10.1016/j.gloplacha.2006.12.004 